\title{
Highly Productive Polar Forests from the Permian of Antarctica
}

Molly F. Miller ${ }^{1}$, Nichole E. Knepprath ${ }^{2}$, David J. Cantrill ${ }^{3}$, Jane E. Francis ${ }^{4}$, John L. Isbell 5

1.Department of Earth and Environmental Sciences (Corresponding author)

Stevenson Center 5726

Vanderbilt University

Nashville, TN 37240 USA

Molly.Miller@Vanderbilt.edu

615-322-3528

2.Mount Isa Mines

Mount Isa,

Queensland, 4825, Australia

nknep@yahoo.com

61409918172

3.Royal Botanic Gardens Victoria,

Private Bag 2000

South Yarra

Victoria, Australia 3141

David.Cantrill@rbg.vic.gov.au

61392522301

${ }^{4}$ British Antarctic Survey

High Cross, Madingley Road

Cambridge, CB3 0ET

United Kingdom

janefr@bas.ac.uk

01223221449

${ }^{5}$ Department of Geosciences

University of Wisconsin - Milwaukee,

3209 N. Maryland Ave.

Milwaukee, WI, 53201 USA.

jisbell@uwm.edu

414-229-2877

C 2015. This manuscript version is made available under the Elsevier user license 


\section{Abstract}

Two stratigraphically closely spaced bedding planes exposed at Lamping Peak in the Upper Buckley Formation, Beardmore Glacier area, Antarctica contain abundant in situ stumps ( $\mathrm{n}=53, \mathrm{n}=21)$ and other plant fossils that allow reconstruction of forest structure and biomass of Glossopteris forests that thrived at $\sim 75^{\circ} \mathrm{S}$ paleolatitude in the Permian. Mean trunk diameter is 14 and $25 \mathrm{~cm}$, corresponding to estimated mean maximum heights of 12 and $19 \mathrm{~m}$. Basal areas are 65 and $80 \mathrm{~m}^{2} \mathrm{ha}^{-1}$. The above ground biomass was calculated using allometric equations for Ginkgo biloba, yielding biomasses of 147 and $178 \mathrm{Mg} \mathrm{ha}^{-1}$. Biomass estimates based on comparison with biomass of modern forests with equivalent basal areas are higher $\left(225-400 \mathrm{Mg} \mathrm{ha}^{-1}\right)$. The amount of above ground biomass added each year (Annual Net Primary Productivity), based on biomass estimates and growth rings in silicified plant material from the Buckley Formation nearby, is poorly constrained, ranging from $\sim 100-2000 \mathrm{~g} \mathrm{~m}^{-2} \mathrm{yr}^{-1}$.

Compared to modern forests at all latitudes, the Permian forests have high basal areas and high biomass, exceeded in both only by forests of the U.S. Pacific northwest and Sequoia forests. The estimated range of productivity (ANPP) is within that of many very productive modern forests. The Lamping Peak forests' basal areas and calculated biomass are also larger than younger high paleolatitude fossil forests except for Arctic Cenozoic forests.

Presence of these highly productive fossil forests at high paleolatitude is consistent with hothouse conditions during the Late Permian, prior to the eruption of the Siberian flood basalts. 
Keywords: fossil forest, high paleolatitude, Antarctica, Permian

\section{Introduction}

In situ stumps representing fossil forests provide information about forest structure, biomass and productivity that is not recorded in plant macrofossils or microfossils (e.g., Francis, 1991; Mossbrugger et al., 1994; Williams et al., 2003; Thorn, 2005; Williams et al., 2009; DiMichele and Falcon-Lang, 2011; Rößler et al., 2012). Because forest characteristics are controlled by environmental factors including temperature, precipitation, soil type, and nutrient availability, they contribute to the reconstruction of paleoclimate, particularly if the paleogeographical settings of the fossil forests are well constrained (e.g., Creber and Chaloner, 1985; Taylor et al., 1992; Francis et al., 1993; Williams et al., 2009). High latitude forests are of special interest, as forests in these regions are especially sensitive to climate change. Ancient high paleolatitude forests give insight into forest distribution, structure, and carbon cycling during periods of greenhouse, icehouse, and hothouse conditions and during transitions between climate states (Kidder and Worsley, 2010).

Numerous well-described Mesozoic (e.g., Jefferson, 1982; Pole, 1999; Cúneo et al., 2003; Thorn, 2005); and Cenozoic (e.g., Basinger et al., 1994; Williams et al., 2003; Williams et al., 2009) forests document prolific forest growth at high latitudes and constrain paleoclimate during these periods. For example, high southern 
latitude Jurassic fossil forests in New Zealand have high biomasses that reflect warm to cool temperate conditions with high seasonal rainfall (Pole, 1999; Thorn, 2005; Williams, 2007). Relatively warm climates at northern high latitudes existed into the Cretaceous, as evidenced by large logs, in situ stumps, and floral composition (Parrish and Spicer, 1988; Spicer and Herman, 2010). However, tree height and density decreased toward the end of the Cretaceous as the climate cooled (Spicer and Chapman, 1990). Polar warmth reached its zenith in the Paleocene to early Eocene, promoting the development of Metasequoia forests at high northern latitude, with biomasses several times those of modern lower latitude temperate forests (Williams et al., 2003). Cooling during the Oligocene - early Miocene resulted in replacement at northern polar latitudes of the deciduous Metasequoia with pines and reduction of forest biomasses to those characteristic of modern temperate forests (Williams et al., 2008; Taggart and Cross, 2009). With continued cooling modern boreal forests were established.

In contrast to the numerous high-latitude Mesozoic and Cenozoic age fossil forests, the only Permian polar in situ fossil stumps previously described are from the same unit and same area as the Lamping Peak forests: the Buckley Formation of the Central Transantarctic Mountains (Mt. Achernar, Graphite Peak, Mt. McIntyre; Wahl Glacier; Taylor et al., 1992; Taylor et al., 1997; Taylor et al., 2000; Taylor and Ryberg, 2007; Gulbranson et al., 2012; 2014). The growth of these trees at $\sim 75^{\circ}$ south latitude on floodplains of braided stream systems implies a vastly warmer climate. In addition to stumps, the Buckley Formation in this area contains permineralized wood with growth rings, leaves, and permineralized peat, 
augmenting paleoclimate information and providing a wealth of information about the floristic composition and plant anatomy (e.g., Taylor et al., 1992; Cúneo et al., 1993; Pigg and Taylor, 1993; Taylor et al., 2000; Taylor and Ryberg, 2007;

Decombeix, 2010; Ryberg and Taylor, 2013; Gulbranson et al., 2014).

The previously described stumps in the Buckley Formation proved that sizable trees grew at polar latitudes during the Permian, but the small number at each site $(<16)$ precluded reconstruction of the forest with sufficient confidence to allow comparison with other ancient or modern forests.

The two closely spaced Lamping Peak forests discovered in 2003 differ from previously described Permian forests in the large number of stumps exposed on horizontal bedding planes (LP1=53 stumps; LP2= 21 stumps).

The purpose of this study was to describe the fossil plant material at Lamping Peak, to reconstruct the attributes of the Lamping Peak forests (tree height, spacing) and their forest structure, to estimate the biomass and yearly productivity of the forests, to compare them to younger high latitude fossil forests and to modern forests, and to explore the paleoclimate implications.

\section{Setting}

\subsection{Geologic, paleogeographic, paleoenvironmental and paleoclimatic context}

The Permian fossil forests occur in the Buckley Formation near the top of Lamping Peak (S 84⒓6"; E 164 40.7”) in the Beardmore Glacier area (Fig. 1). At the time, the Beardmore area was well within the southern polar circle, probably at a latitude higher than $70^{\circ}$ S (Powell and Li, 1994; Lawver et al., 2008; Isbell et al., 2012). 
The Buckley Formation is part of a thick Lower Permian to Lower Jurassic sedimentary sequence deposited in a subsiding foreland basin (Collinson et al., 1994). During the Jurassic the sequence was intruded by sills (Ferrar Dolerite) generated during the break-up of Gondwana.

The Permian sequence consists of: 1) glacigenic, primarily glacial marine and glacial lacustrine deposits recording Gondwanan glaciation (Pagoda Formation, Isbell et al., 1997; 2001; 2008); 2) shale and interbedded sandstone deposited in a large post-glacial lake or series of lakes filled by deltaic sediments (Mackellar Formation and lowermost Fairchild Formation, Miller, M.F., et al., 2010); 3) crossbedded sandstone lacking plant fossils deposited in braided stream channels (bulk of Fairchild Formation, Barrett et al., 1986); and sandstone, siltstone, shale and coal deposited in braided stream systems (Buckley Formation, Isbell, 1990; Isbell et al., 1997; Gulbranson et al., 2012, 2014). The amount of plant material and the thickness and extent of coal increases upward within the Buckley Formation. Trees, particularly in the Buckley sediments deposited in the Late Permian, grew on vegetated bars, levees, crevasse splays, and lake margins.

The Permian succession in the Beardmore Glacier area of the Central Transantarctic Mountains reflects a transition in the Permian from icehouse to greenhouse to hothouse conditions (e.g., Kidder and Worsley, 2004; 2010; Shi and Waterhouse, 2010). The Pagoda Formation records the Late Paleozoic Ice Age and the Mackellar and Fairchild Formations were deposited as the climate warmed in response to rising $\mathrm{CO}_{2}$ levels (Montanez et al., 2007). Proliferation of southern polar forests during Buckley Formation deposition in the Middle to Late Permian reflects 
continued warming. Massive volcanic eruptions in the Middle and latest Permian (Emeshian and Siberian flood basalts) are implicated in releasing $\mathrm{CO}_{2}$ and methane, leading to a series of cascading global events resulting in hothouse conditions that are implicated in extinction events, including the end-Permian extinction (Bond et al., 2010; Shi and Waterhouse, 2010; Kidder and Worsley, 2010; Joachimski et al., 2012). Unfortunately, there is insufficient biostratigraphic control and radiometric dating to closely link the Lamping Peak forests in time to these events. However, there is no question that the Lamping Peak forests were thriving during the Late Permian and that they record the response of Permian polar vegetation to hothouse conditions.

\subsection{Depositional environments - Lamping Peak}

The sedimentary succession of the Buckley Formation at Lamping Peak (Figs. 2,3 ) is dominated by fine-grained sandstone with subordinate siltstone. In the lower part of the section, large-scale crossbedded sandstone records deposition in channels with flow to the southwest (Fig. 2; Flaig, 2005; Knepprath, 2006). The majority of the sequence consists of horizontally bedded fine sandstone and siltstones recording unconfined flow outside of the channels, as on crevasse splays, and overland flow on floodplains. Some of the siltstones are poorly developed paleosols. The absence at Lamping Peak of thick coal and thick shale deposits suggests deposition close enough to the stream channels to receive sand-sized material, although under predominantly low-energy conditions.

The fossil forests (LP1 and LP2) are exposed on two bedding planes within two meters of each other near the top of the section (Figs. 2, 3). The stumps occur in 
weakly developed paleosols, within a typical sequence of horizontally bedded fine and very fine-grained sandstone. The trees grew outside of braided stream channels, on crevasse splays or on floodplains.

\section{Methods}

\subsection{Field methods}

A measured section of the Buckley Formation at Lamping Peak was constructed, including lithology, and the distribution of physical and biogenic sedimentary structures (Fig. 2). In addition to locating the closely spaced stump horizons that record the fossil forests near the top of the section, we noted the location, abundance, and type of leaves, and estimated abundance of macerated plant material on bedding planes. Maximum diameter of 125 pieces of large woody debris (LWD) at five plant-bearing horizons was measured. Orientations of 38 logs on three bedding planes stratigraphically close to the stump horizons were recorded (Fig. 2). A map of stumps in each fossil forest exposure was constructed by measuring the distance between stumps (center to center) and the direction using point and compass. Diameter of each stump was measured and recorded on the map.

Material replacing the organic matter of the stumps was collected and the mineral content determined by x-ray diffraction and XANES analysis (Knepprath, 2006).

\subsection{Analysis of fossil forests}

Tree height for each stump was determined using interspecific allometric relationships between basal stem diameter of woody plants and tree height (Niklas, 
1994). In modern forests the trunk diameter at breast height (DBH; $1.4 \mathrm{~m}$ above ground) is used for the basal stem diameter. Fossil stumps, including those at Lamping Peak, typically have little or no relief, so diameter at ground line (DGL) commonly is used for basal stem diameter.

To facilitate comparison with modern forests and some fossil forests, we estimated DBH from DGL of stumps in the Lamping Peak forests using the regression equation of McClure (1968). This equation is based on the tapering and root flare trends of 55 extant species of trees in the southeastern United States; the coefficients vary depending on tapering, which is unknown for the extinct Glossopteris. However, large logs ( $>2 \mathrm{~m}$ in length) preserved on bedding planes elsewhere at Lamping Peak displayed only gradual tapering. We calculated DBH for each stump in LP1 and LP2 using the coefficients for each of the 55 modern species; DBH for a particular trunk was the mean of the 55 calculated DBH. From the mean DBH for each stump, maximum height was calculated using the woody stem regression equation of Niklas (1994).

Two methods were used to calculate stand density, the number of trees per unit area (trees ha-1). The point-center quarter method (pcq) quantifies the location of stumps in quadrants defined by points along transects in a forest (Cottam and Curtis, 1956). It has been used to estimate stand density in fossil forests including Permian and Triassic forests in the Transantarctic Mountains (Taylor et al., 1991; Cúneo et al., 1993; Cúneo et al., 2003). Four 30 m long transects were done at LP 1 and two at LP 2, with points at $10 \mathrm{~m}$ and $5 \mathrm{~m}$ intervals. 
Stand density of fossil forests was calculated by determining the number of in situ stumps in a given area and converting it to trees per hectare ( $\mathrm{t} \mathrm{ha}{ }^{-1}$; Jefferson, 1982; Francis, 1991; Basinger et al., 1994; Greenwood and Basinger, 1994; Pole, 1999; Falcon-Lang et al., 2001). Although we knew the number of trees in LP1 and LP2, we were uncertain of the location of the forests' boundaries. To estimate forest area, we measured the distance between each stump and its nearest neighbor (n.n.), determined the mean n.n. distance, drew a circle with radius = mean n.n. around each stump, and constructed the perimeter of the area by enclosing the circles. To constrain maximum and minimum forest area for LP1 and LP2, we used the largest and smallest n.n. values for the radius of each circle, and used the circles to determine the perimeters of the maximum and minimum forest areas. We then converted the number of trees in areas of the LP1 and LP2 forests to number of trees per hectare $\left(\mathrm{t} \mathrm{ha}^{-1}\right)$.

Basal area is the total cross-sectional area of trunks at breast height in a given area (Cottam and Curtis, 1956). Trunk area was calculated for both DGL (for comparison to many fossil forests) and DBH (for comparison to modern and some fossil forests). We used forest areas determined from both the pcq and n.n. methods.

Determining above ground biomass of the LP1 and LP2 forests is difficult because only stumps and some roots are preserved in situ and because the forests were dominated by Glossopteris (see 4.2 below) which has been extinct since the beginning of the Mesozoic. We used two approaches to estimate total forest biomass of LP1 and LP2. First, we estimated the volume of each LP1 and LP2 tree 
using an allometric equation for Ginkgo biloba tees in urban Korea (Yoon et al., 2013) and multiplied it by the density of Ginkgo biloba wood $\left(0.5267 \mathrm{~g} \mathrm{~cm}^{-3}\right.$;

BenHua et al., 2000). The long-extinct Glossopteris has no close extant relatives. Ginkgo was chosen as an analog for Glossopteris as both groups have a short shoot long shoot branching system and broad leaves, although the leaves in Glossopteris are much broader and have a different venation pattern.

In the second approach, we plotted published basal area to biomass data from the literature on modern forests and bracketed the potential ranges of biomass of the fossil forests based on the range of basal area to biomass ratios of modern forests.

To constrain the biomass added each year (productivity; Annual Net Primary Productivity - ANPP) we divided the biomass by the age of the tree determined by dividing the DBH of the tree by the mean widths of growth rings from seven specimens of silicified wood taken from the Buckley Formation at Skaar Ridge, $100 \mathrm{~km}$ from Lamping Peak and one from the Buckley Formation $200 \mathrm{~km}$ to the south of LP1 and LP2 (Taylor and Ryberg, 2007). Three tree ages were calculated for each tree based on 1) mean of mean widths of growth rings in the eight specimens; 2) mean of means of smallest widths of growth rings in the eight specimens; and 3) mean of means of largest widths of growth rings in the eight specimens.

We calculated monthly rates of net primary productivity by dividing the estimated annual net primary productivity values by two estimates of the number of months in the growing season, 3 months and 7 months. The short 3 month growing 
season reflects estimates of duration of growing in Antarctica of 48 days in the Early Permian (Francis et al., 1994) and 58 days later in the Permian (Taylor and Ryberg, 2007); their estimates are based on the number of cells in the fossil growth rings divided by rate of cell production (up to 4 cells per day) in modern spruces (Creber and Chaloner, 1984). The seven month growing season is based on the present day Arctic light regime and the number of months with $\sim 8$ hours or more of daylight at 75 N (Spicer and Herman, 2010, Fig. 8).

\section{Results}

\subsection{Plant material at Lamping Peak}

Four types of plant fossil occur in the $55 \mathrm{~m}$ of Buckley Formation at Lamping Peak, including in situ stumps, large woody debris (LWD), fragments of leaves and macerated plant material.

\subsubsection{Stumps}

Seventy-four stumps occur in two layers near the top of the measured sections, separated stratigraphically by two $\mathrm{m}$ (Fig. 2,3; LP1, $\mathrm{n}=53$; LP2, $\mathrm{n}=21$ ). We interpret the stumps as in situ because stumps are upright, contained within siltstone units with roots extending outward from the stumps (Fig. 4) and because the stumps are surrounded by densely packed impressions of Glossopteris leaves. The stumps occur in thin poorly developed paleosols with a presumed high water table, as suggested by the shallow roots and Vertebraria and an abundance of adjacent sheet sandstones interpreted as crevasse splays (Fig. 2; Flaig, 2005; Knepprath, 2006). The overlying trunks appear to have been snapped off at the base. 
The stumps have been replaced by a magnetite, as determined by x-ray diffraction and XANES analysis (Knepprath, 2006). Boundaries between the stumps and the surrounding rock are sharp, indicating that the full diameter of the trunk was replaced by the magnetite, but the replacement did not preserve growth lines or other anatomical structures. We suggest that the magnetite replacement was facilitated by hydrothermal fluids generated by intrusion of the Ferrar Dolerite associated with the break-up of Gondwana in the Jurassic. The $55 \mathrm{~m}$ of Buckley Formation at Lamping Peak directly overlies a thick ( $>50 \mathrm{~m}$ thick) sill of Ferrar Dolerite (Figs. 2, 3)

\subsubsection{Leaf mats}

Stumps are surrounded by thin layers of siltstone to very fine-grained sandstone packed with superimposed impressions of Glossopteris leaves (Fig. 4). Similar leaf-rich layers in the Buckley Formation in the Beardmore area and elsewhere in Antarctica are referred to as leaf mats, (e.g. Cúneo et al., 1993; Taylor et al., 2000; Taylor and Ryberg, 2007). Although post-depositional fractures in the rock at Lamping Peak have broken the impressions, it appears that few of the leaves were whole even prior to the fracturing.

\subsubsection{Large woody debris}

Impressions of branches and logs are scattered throughout the Lamping Peak section, with the diameter of the logs increasing to more than $70 \mathrm{~cm}$ toward the top of the section near the fossil forests (Fig. 2; Knepprath, 2006, Fig. 35). Orientations of $35 \log$ impressions on 3 closely spaced sandstone-bedding planes above the LP2 forests were measured. On two bedding planes the $\operatorname{logs}(n=10 ; n=11)$ are oriented 
NW-SE with a smaller NE-SW component, whereas on the third bedding plane the predominant orientation of the logs $(\mathrm{n}=17)$ is NE-SW with a secondary orientation of NW-SE (Knepprath, 2006). The stratigraphic proximity of the logs to the fossil forests implies that the logs were not transported far. It also suggests restriction of the forests to certain areas; if the entire area had been covered by forest, large woody debris would have been distributed throughout the stratigraphic section.

\subsubsection{Macerated plant material}

Coalified macerated plant debris is scattered throughout the Lamping Peak section, but is rarely abundant on bedding planes.

\subsection{Type of trees in Lamping Peak fossil forests}

Glossopterid leaf fossils are extremely abundant in Antarctic Permian deposits, indicating that this plant dominated the ecosystem (Francis, 1993; Cúneo et al., 1993; Cantrill and Poole, 2012). That the Lamping Peak forests were composed of trees bearing Glossopteris leaves is backed by composition of fossil plant material in the Buckley Formation in the Beardmore area within $100 \mathrm{~km}$ of Lamping Peak, including some that is exquisitely preserved in permineralization peat, as well as by plant fossils at Lamping Peak. In two quantitatively sampled plant sections in the Buckley Formation at Mt. Achernar, $\sim 50 \mathrm{~km}$ from Lamping Peak, $56 \%$ and $68 \%$ of bedding plane surfaces are covered with plant material, with $100 \%$ of identifiable plant material composed of Glossopteris leaves in one section, and 94\% composed of Glossopteris leaves with the other 6\% composed of Plumsteadia ovata, a reproductive structure associated with Glossopteris (Cúneo et al., 1993, Table 1). Eighty five percent of bedding plane surfaces at two horizons in 
the Buckley Formation at Mt. Picciotto are covered with plant material, $100 \%$ of the non-stem identifiable material consists of Glossopteris leaves; Vertebraria, the distinctive root structures of Glossopteris also occur in both horizons (Cúneo et al., 1993). The profuse leaf covers on bedding planes have been interpreted as leaf mats that accumulated during leaf drop, implying a deciduous habit for Glossopteris (Cúneo et al., 1993; Taylor et al, 2000) however, Gulbranson et al. (2014) recently suggested that glossopterids in the Beardmore area included both deciduous and evergreen habits.

The Buckley Formation at Skaar Ridge, 100 km from Lamping Peak has permineralized peat with anatomically preserved structures, including a stem with an attached Glossopteris leaf (Pigg and Taylor, 1993). The wood in the peat is exclusively Araucarioxylon, the wood of Glossopteris; no other woody material occurs, although Vertebraria is also found.

The plant material at Lamping Peak is not as well preserved as that at Skaar Ridge or elsewhere in the Beardmore Glacier area (Pigg and Taylor, 1993; Taylor and Ryberg, 2007), but it has characteristics linking it to Glossopteris: 1) The impressions of the leaves, although fractured, are large enough to preserve the glossopterid venation pattern and no leaves other than those of glossopterids were found; 2) The roots emanating from the stumps include Vertebraria structures; 3) Large straight logs that are meters long have few branches, similar to glossopterids in southern Victoria Land (Francis, 1993).

Given the dominance of glossopterids in the Buckley Formation and in other Permian deposits in Antarctica, the linkage of Glossopteris leaves to the only type of 
woody material that is preserved in the Buckley Formation, and the presence at Lamping Peak of Glossopteris as the only leaf type and of Vertebraria, we follow previous workers (e.g., Gulbranson et al., 2012; Gulbranson et al., 2014) and interpret Lamping Peak forests to have been composed of trees bearing Glossopteris leaves.

\subsection{Characteristics of fossil forests}

\subsubsection{Stump diameters, distribution, density; tree height and basal area}

The spatial distribution of stumps of different sizes in the bedding plane exposures of LP1 and LP2 are shown in Fig. 5. Stumps of diverse sizes are dispersed on the bedding plane surfaces. The size frequency distribution (Fig. 6) of trees in LP1 differs significantly from those in LP2 $\left(X_{2}=43.85: p=99{ }_{(7)}=20.09\right.$; Dixon and Massey, 1969), with LP2 having a higher proportion of larger diameter stumps. Mean diameter of stumps at ground level in LP2 $(39 \mathrm{~cm} ; \mathrm{n}=21)$ is larger than in LP1 (21 cm, n=53; Table 1). Estimated diameter at breast height (DBH) of stumps in LP2 (mean=25 cm) are correspondingly larger than those in LP1 (mean=14 cm; Table 1). The trees were tall, especially in LP2 with a mean maximum height based on DGL of $25 \mathrm{~m}$ (Table 1) with those in LP1 somewhat shorter (15 m); mean maximum heights based on DBH differ slightly (LP2=19 m; LP1=12 m).

Densities of trees in both LP1 and LP2 are high at 2505 trees ha-1 $^{-1}$ LP1) and 1185 trees ha-1 $^{-1}$ LP2) (Table 1), based on average densities calculated using both the point-centered quarter and nearest neighbor methods. At these stand densities, the basal area of LP2 calculated using DGL is $194 \mathrm{~m}^{2} \mathrm{ha}^{-1}$ and that of LP1 is $173 \mathrm{~m}^{2} \mathrm{ha}^{-1}$ 
(Table 1); using DHB as used for calculation of basal areas of modern forests, the basal areas are $80 \mathrm{~m}^{2} \mathrm{ha}^{-1}$ for LP2 and $65 \mathrm{~m}^{2} \mathrm{ha}^{-1}$ for LP1.

\subsubsection{Estimates of tree age, forest biomass, and productivity}

Estimating biomass for Paleozoic forests composed of trees with no close modern analogues is problematic (see discussion below) but can be constrained based on wood density and allometric equations for Ginkgo biloba, suggested to be the closest living relative of the abundant Permian glossopterids. These parameters yield above ground biomass estimates of $178 \mathrm{Mg} \mathrm{ha}^{-1}$ for LP2 and $147 \mathrm{Mg} \mathrm{ha}^{-1}$ for LP1 (Table 1).

Biomass estimates based on biomass of modern forests with basal areas similar to those of LP1 and LP2 yield higher values than those based on analogy to Gingko biloba (Table 1; Fig. 7). Estimated above ground biomass of LP1 ranges from $225 \mathrm{Mg}$ ha-1 to 340 and of LP2 from 290 to 400 (Fig. 7 , Table 1).

Estimation of productivity, biomass per unit time, (Annual Net Primary Productivity [ANPP]) requires tree age. Based on mean mean, mean maximum, and mean minimum thicknesses of growth rings in silicified wood from nearby outcrops of the Buckley Formation (Taylor and Ryberg, 2007), the estimated mean, minimum, and maximum ages of LP1 trees are 59, 33, and 150 years respectively, and those of LP2 trees 109, 61, and 275 years. Dividing biomass estimates based both on Gingko biloba and comparison with modern forests with equivalent basal areas yields bracketed estimates of ANPP of 105 to $2060 \mathrm{Mg} \mathrm{ha}^{-1}$ (for LP1) and of 109 to 1310 $\mathrm{Mg} \mathrm{ha}^{-1}$ (for LP2) (Tables 1, 2). Lowest rates of annual productivity come from those estimated using biomass equations for Gingko biloba (Table 2). 
Estimates of monthly rates of net primary productivity (eNPP) vary widely depending both on the estimate of the length of growing season used (3 or 7 months; Table 2) and on the estimate of annual productivity. They range from 15 to $687 \mathrm{~g} \mathrm{~m}^{-2}$, with the lowest rates based on productivity estimates using an allometric equation for Gingko biloba (Table 2).

\section{Discussion}

The large number of in situ stumps in LP1 (n=53) and LP2 (n=21) forests provide the most extensive data set available for quantifying Permian high paleolatitude forest structure, biomass, and productivity. It forms a solid basis for comparison of these fossils forests to modern forests and to Mesozoic and Cenozoic high latitude fossil forests.

\subsection{Comparison to modern forests}

\subsubsection{Stand density, basal area, height, and age}

Stand density, the number of trees per unit area, of LP1 (2505 stems ha-1) and LP2 (1185) are higher than for many modern forests. Deciduous floodplain forests in the southeastern United States have densities of 400-600 stems ha-1 (Megonigal et al., 1997). Tree density changes with the age of the forest; with old growth forests having lower stand densities than younger forests. For example, old growth conifer forests in the Pacific Northwest of the United States have 400-500 stems ha-1 ${ }^{-1}$ whereas younger (20-40 years old) but otherwise comparable forests have 700-1500 stems ha-1 (Williams, 2007). Cypress forests in Florida that are 4475 years old have stem densities that are higher (2100 stems ha-1) than an older (>100 years old) forest with 1644 stems ha-1 $^{-1}$ Brown, 1981). Similarly, stand 


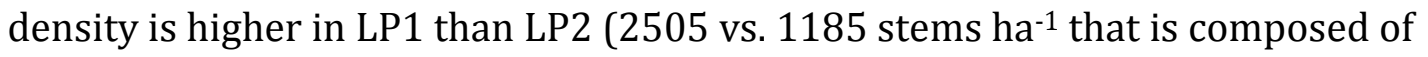
smaller diameter trees (Table 1).

Basal area, the combined cross-sectional area of stemwood in a given area, is a measurement that reflects forest productivity but is independent of forest age. Basal area of modern forests is based on tree diameter at breast height $(\mathrm{DBH}=1.4$ m). DBH for LP1 and LP2 trees were calculated from diameter at ground level using regression equations developed for 55 species of modern trees based on the tapering and root flare characteristics and taking the mean for Lamping forest trees. The validity of this approach is supported by our observations that the taper of impressions of large trunks preserved within a few meters stratigraphically above the upper Lamping forest layer appeared similar in shape to modern trunks.

Basal areas of LP1 $\left(65 \mathrm{~m}^{2} \mathrm{ha}^{-1}\right)$ and LP2 $\left(80 \mathrm{~m}^{2} \mathrm{ha}^{-1}\right)$ are large relative to those of many modern forests (Figs. 7, 8), exceeding the mean values of extant forests at all latitudes by $10 \mathrm{~m}^{2} \mathrm{ha}^{-1}$ or more (Huston and Wolverton, 2009). Basal areas of Lamping Peak forests, which flourished adjacent to braided stream systems, are larger than those of wetland forests of North America $\left(\sim 30-60 \mathrm{~m}^{2} \mathrm{ha}^{-1}\right.$; Brown, 1981, Table 17). The basal areas of Lamping Peak forests could be over estimated if some of the stumps, all of which were assumed to represent living trees, were dead. However, the dead: live ratio of stems in modern floodplain and swamp forests in the southeastern United States is typically less than 0.08 , suggesting that the high basal areas of the Lamping Peak forests are not significantly enlarged by dead trees. 
Height of the Lamping Peak trees is $12-19$ m based on DBH using the woody stem equation of Niklas (1994) (Table 1). It is similar to the height of trees in upland and swamp forests (9-34m, mostly $13-18 \mathrm{~m})$ in the eastern United States (Schlesinger, 1978, Table 8), although less than trees in conifer forests of the US Pacific Northwest and some tropical rain forests (Gholz, 1982).

The frequency distribution of tree diameters in LP1 and LP2 differ, with more small diameter trees in LP1 than LP2 (Fig. 6). In monospecific stands, such as LP1 and LP2 Glossopteris forests, size frequency distributions reflect forest age (Williams, 2007). The more normal distribution of LP2 than LP1 is consistent with an even-age forest, whereas the abundance of small diameter trunks in LP1 suggests an uneven age forest. An even-age forest such as at LP2 would be established during colonization following a forest-destroying flood, an expectable if infrequent event in the Lamping braided stream setting.

\subsubsection{Biomass}

Density, basal area, and tree height allow for physical reconstruction of fossil forests and, for the Lamping Peak forests. However, these characteristics contribute little to the understanding of the productivity of the forest which is related to the allocation and transfer of carbon in the ecosystem and reflects paleoclimate (e.g., Williams, 2007) as well nutrient availability (e.g., Huston and Wolverton, 2009).

Biomass estimates of the Lamping Peak forests using approaches such as those of Williams et al. (2008) are precluded by a dearth of information about the 
above ground shape of Glossopteris and its branching patterns, branch length, and other characteristics (see Cantrill and Poole, 2012, and references therein), and by the absence of a closely related modern tree. However, in the absence both of a close relative and of morphological details about the Glossopteris trees, the two approaches used to estimate biomass (see section 3.2) broadly constrain the biomass of the Lamping Peak forests.

First, we estimated biomass using the allometric equation for Ginkgo biloba that relates DBH to above ground volume (Yoon et al., 2013) and multiplying it by its density (BenHua et al., 2000) (Fig. 7a, b, Table 1). Uncertainties in this approach arise from: 1) unknown taxonomic relationship and anatomical similarity between Ginkgo biloba and Glossopteris, and 2) differences in settings between the urban forests of the Ginkgo biloba (Yoon et al., 2013) and the Permian forests of Glossopteris growing naturally adjacent to braided stream systems. In the second approach we graphed basal area vs. biomass of diverse modern forests and bracketed the biomasses of forests with basal areas within the range of those of the Lamping Peak forests (Fig. 7c). The validity of this approach is supported by Williams' (2007) data-backed suggestion that the fundamental controls on plant productivity, and thus on the functioning of forest ecosystems, have been in place for tens, possibly hundreds of millions of years.

Biomass estimates for LP1 (147 Mg ha-1) and LP2 (178 Mg ha-1) using equations for Ginkgo biloba are lower than those based on a range of modern trees (Table 1, Fig. 7). However, they are larger than estimates of total biomass of 
tropical, temperate, or boreal forests (Huston and Wolverton, 2009, Table 1; 42 $\left.194 \mathrm{Mg} \mathrm{ha}^{-1}\right)$. Bracketed biomass estimates (LP1 $=225-340 \mathrm{Mg} \mathrm{ha}^{-1} ; \mathrm{LP} 2=290-400$ $\mathrm{Mg} \mathrm{ha}^{-1}$ ) are significantly higher than estimated biomasses of most modern forests (Huston and Wolverton, 2009).

Several types of modern forests have different basal area to biomass relationships than most modern forests. A Sequoia forest in the US Pacific Northwest is reported to have a basal area of $330 \mathrm{~m}^{2} \mathrm{ha}^{-1}$ and a biomass of $4000 \mathrm{Mg}$ ha $^{-1}$ (Busing and Fujimori, 2005) and other conifer forests from the Oregon coast to the crest of the Cascade Mountains have very large basal areas and extremely large biomass (Fig. 7a). In addition, tropical forests have high biomasses combined with modest basal areas (Fig. 7a,b). In bracketing the estimated biomasses of the LP1 and LP2, we used the basal area to biomass trend of diverse temperate forests, excluding the very different trends suggested by data from the Sequoia forest, conifer forests of the Pacific Northwest, and tropical rainforests. Inclusion of these forest types in the estimates would have made the biomass estimates even larger.

\subsubsection{Annual Net Primary Productivity}

The amount of biomass added each year (ANPP in $\mathrm{g} \mathrm{m}^{-2} \mathrm{yr}^{-1}$ ) and the eNPP (amount of biomass added per month during the growing season; Huston and Wolverton, 2009) are ecologically important as indicators of the transfer and rate of transfer of carbon through the ecosystem. Estimation of ANPP and eNPP requires data about yearly growth rates, which is unavailable for LP1 and LP2. Silicified wood with well preserved growth rings from the Buckley Formation $\sim 100 \mathrm{~km}$ from 
LP1 and LP2 provide bracketed growth rates (Taylor and Ryberg, 2007), from which ANPP and eNPP can be calculated (Tables 1 and 2). Although these estimates include uncertainty both about the biomass and about the yearly growth rates, and for the eNPP, the length of the growing season, they provide information about the ranges of possible ANPP and eNPP values of LP1 and LP2 forests.

The estimated above ground ANPP of LP1 and LP2 (Tables 1, 2) are within range of those of many highly productive forests worldwide. Above ground ANPP of modern upland and swamp forest range from $600-1700 \mathrm{~g} \mathrm{~m}^{-2} \mathrm{yr}^{-1}$ with most 700 $1100 \mathrm{~g} \mathrm{~m}^{-2} \mathrm{yr}^{-1}$ (Schlesinger, 1978). Evergreens at elevations of $<2000 \mathrm{~m}$ in the Himalaya produce $\sim 1300 \mathrm{~g} \mathrm{~m}^{-2} \mathrm{yr}^{-1}$ (Singh et al., 1994) whereas for floodplain deciduous forests in the SE United States, the ANPP is 700-1200 $\mathrm{g} \mathrm{m}^{-2} \mathrm{yr}^{-1}$ (Megonigal et al., 1997). The ANPP of a Sequoia forest in the Pacific Northwest of the US is $760 \mathrm{~g} \mathrm{~m}^{-2} \mathrm{yr}^{-1}$, which is small compared to its huge biomass (4000 $\mathrm{Mg} \mathrm{ha}^{-1}$ ) (Busing and Fujimori, 2005).

At a paleolatitude of $\sim 75^{\circ} S$, the growing season of LP1 and LP2 forests was $\sim 7$ months based on light availability (Spicer and Herman, 2010). However, estimates based on number of cells in growth rings and rate of cell production in modern trees suggests a growing season of $\sim 3$ months or less. Disparity in the length of growing season applied yields a very large range in eNPP for LP1 and LP2 (15-687 $\mathrm{g} \mathrm{m}^{-2}$ month$^{-1}$ ), which is within the range of modern eNPP at all latitudes. Using the short growing season the range of eNPP for LP1 and LP2 encompasses and 
exceeds the means of eNPP in modern forests in all latitudinal zones (Huston and Wolverton, 2009, Fig. 11).

Comparison with modern forests is facilitated by the area preserved in the Lamping forests, far larger than that of other Permian high latitude forests. This allows realistic assessment of attributes such as stand density, stem diameter frequency distribution, tree height, and basal area. The basal areas of the forest exceed those of most modern forests. There are more uncertainties in estimating biomass than basal area, uncertainties arising from limited basis for uniformitarian comparison. However, bracketed estimates of biomass, above ground annual net primary productivity (ANPP), and growth rate per month during the abbreviated growing season all point to productive polar forests in the Permian.

It is possible that the high productivity was stimulated by high $\mathrm{CO}_{2}(>2000$ ppm) at the end of the Permian (Royer et al., 2004). Modeling incorporating experimental data on effects of elevated $\mathrm{CO}_{2}$ on rates of photosynthesis, respiration, and transpiration suggests that basal wood growth can be increased by $20-25 \%$ by high $\mathrm{CO}_{2}$ levels (Osborne and Beerling, 2002).

\subsection{Comparison to other high paleolatitude fossil forests}

\subsubsection{Permian forests, Antarctica}

Widespread Permian fluvial deposits in Antarctica contain plant material including coal, palynomorphs, leaf impressions and carbonaceous films, permineralized peat, seeds, and wood. Diversity is low, with macrofloras heavily dominated by glossopterids (Cantrill and Poole, 2012, Table 3.1). Large trunks of 
Permian wood occur in the Prince Charles Mountains (Australian sector; Weaver et al., 1997) and in southern Victoria Land (e.g., Francis et al., 1993). Well-preserved growth lines in this wood yield paleoclimate information (e.g. occurrence or lack of frost damage during growing season) and provide direct insight into the age of the trees. However, in situ stumps are known only from the Buckley Formation in the Beardmore and Shackleton Glacier areas (Table 3).

Whereas the diameter and estimated heights of some of the in situ stumps resemble those in the Lamping Peak forests, their small numbers produce uncertainty when extrapolated to forest scale. The Mt. Achernar forest was dominated by small-diameter trees. Its basal area, like that of the Graphite Peak and Wahl Glacier forests, was 30\% of the basal area of the Lamping Peak forests. If the Lamping Peak trees grew at rates similar to those at nearby Skaar Ridge, Lamping Peak forests' greater basal area, and presumably greater biomass suggests that they were more productive than the other forests. It also supports Gulbranson et al.'s (2012) conclusion that Permian forest coverage and structure in the high paleolatitude Beardmore area were variable. They attribute the high productivity of the Lamping Peak forests to growth on a distal floodplain, relatively unaffected by dynamic events associated with crevasse splays and channel margins, their inferred setting for the Wahl Glacier and Graphite Peak forests. We interpret the bimodal orientation of large logs just above the Lamping Peak forests to reflect fluvial transport, and note that the Lamping Peak stratigraphic section is dominated by sand, rather than siltstone and shale that would record distal floodplain/lacustrine margin deposition (Knepprath, 2006). 
The LP1 and LP2 apparently were more productive than the other contemporaneous forests that developed under similar paleoclimate, paleoenvironmental and soil nutrient conditions, which were enhanced by the occurrence of volcanic rock fragments in the sand (Barrett et al., 1986; Isbell, 1990). The factors that promoted forest growth at Lamping Peak remain elusive, but careful reconstruction illustrates how thriving they were even at Permian polar latitudes (Fig. 9).

\subsubsection{Younger high-latitude forests}

The Lamping Peak forests resemble or surpass Triassic and Jurassic high latitude forests in tree diameter, tree height, and stand density (Table 4). Their stem densities and basal areas are 3-4 times that of the (nearby-Gordon Valley) Triassic forest, implying a greater biomass. Although the Curio Bay, New Zealand Jurassic forest is an outlier, with an anomalously low basal area: biomass ratio, the Jurassic conifer forest (New Zealand; Thorn, 2005) surpasses the LP1 and LP2 forests in basal area and in estimated biomass.

Late Paleocene and Eocene high northern latitude forests were dominated by deciduous broadleaf hardwoods and deciduous conifers, particularly, Metasequoia, (Taggard and Cross, 2009) and were characterized by large basal areas and high biomass (Table 4). They flourished in Arctic wetlands, attaining heights $>40 \mathrm{~m}$ throughout a late Paleocene-Eocene warm period, during which average annual temperatures were $25-30^{\circ} \mathrm{C}$ warmer than today (Williams et al., 2003; Williams, 2007; Williams et al., 2010; Miller, G.H., et al., 2010). These early Cenozoic Arctic forests were more productive than the high southern latitude Permian Lamping 
Peak forests, and were equivalent to the highly productive modern conifer forests of the Pacific NW.

Yearly above ground productivity of the Metasequoia forest was 5 to $7 \mathrm{Mg}^{\mathrm{M}} \mathrm{a}^{-}$ ${ }^{1} \mathrm{yr}^{-1}$, which is similar to that of a modern Sequoia forest $\left(8.5 \mathrm{Mg} \mathrm{ha}^{-1} \mathrm{yr}^{-1}\right.$, Busing and Fujimori, 2005) and within the range of temperate conifer forests of the US Pacific NW (4.2-15 Mg ha-1 $\mathrm{yr}^{-1}$; Gholz, 1982). The ratio of biomass to annual above ground productivity (AAGP) of the Cenozoic Metasequoia forest was high ( 100:1) but not as high as the modern Sequoia forest ( 470:1); biomass: AAGP ratios of conifer forests in the US Pacific NW are 57-116:1; Gholz, 1982), lower than that of the Sequoia forest. In the Sequoia and other conifer forests of the US Pacific NW the massive biomass is stored in the wood of the trunk and stems, with only moderate addition each year. Temperate deciduous forests of the southeastern US have somewhat higher annual net above ground primary productivity than the Sequoia forest (9-17 Mg ha-1 $\mathrm{yr}^{-1}$; Megonigal et al., 1997); ratios of biomass: AAGP in two temperate deciduous forests are lower $(45: 1 ; 25: 1$; Schlesinger et al., 1978) than for Pacific NW or Sequoia forests. We estimated the biomass: AAGP ratio for LP1 to range from 29:1 to 55:1, and for LP 2 to range 55:1 to 64:1, closer to the temperate deciduous forests than to extremely high productivity Cenozoic Metasequoia or modern forests in the Pacific NW of the United States.

Two interpretations of why the Lamping Peak forests more closely resemble modern temperate forests than the high biomass Cenozoic Metasequoia polar forests are possible: 1) Glossopterids had not evolved the structures and processes that allow for Sequoia-like growth, and 2) Permian polar temperature and 
precipitation regimes did not meet requirements for Metasequoia-like growth. The first is supported by recent discovery of Permian glossopterid anatomical structure that may have affected water transport (Decombeix, 2010); other as yet unknown features may have limited glossopterid productivity as well. The second is supported by the decline in Metasequoia dominated forests that correlated with mid-Cenozoic cooling and their replacement by more cold-resistant conifers (Taggart and Cross, 2009; Opalinska and Cowling, 2013).

\section{Paleoclimate Implications}

Permian rocks record changes in climate, driven by changes in $\mathrm{\rho C}_{2}$ (Royer et al., 2004). The Late Paleozoic Ice Age (LPIA) lasting from 320-290 Ma (Shi and Waterhouse, 2010) involved a shifting mosaic of ice-related environments in the southern hemisphere, the dynamics of which impacted climate worldwide (Montanez and Paulsen, 2013). Deglaciation during the Early Permian involved an overall increase in $\mathrm{\rho C}_{2}$, albeit with large fluctuations, and this and related temperature rise caused demonstrable floral change (Montanez et al., 2007). An increase in temperature continued through the Permian, with a Late Permian $8^{\circ} \mathrm{C}$ rise in sea surface temperature indicated by high-resolution oxygen isotope records from conodont apatite from South China (Joachimski et al., 2012). Permian stratigraphic units in the Central Transantarctic Mountains reflect this paleoclimate change (see section 2.1 above).

Permian climate change has been attributed to a transition from icehouse to greenhouse (Shi and Waterhouse, 2010) or from icehouse to greenhouse to hothouse (Kidder and Worsley, 2004; 2010). Greenhouse conditions dominated the 
Phanerozoic, including most of the Paleozoic, but in the mid-late Paleozoic a climate cooling caused by a drop in $\rho \mathrm{C}_{2}$ related to weathering of silica-rich rocks uplifted during continent-continent collision, culminated in LPIA (Shi and Waterhouse, 2010; Montanez and Paulsen, 2013). Cessation of collision allowed rebound of $\mathrm{\rho C}_{2}$ to greenhouse levels and temperatures, providing positive warming feedbacks and the development of hothouse conditions (Kidder and Worsley, 2010). Extrusion of the massive Siberian Traps at the end of the Permian may have initiated the greenhouse to hothouse transition (Reichow et al., 2009). The outpouring of carbon dioxide and methane into the atmosphere is interpreted to have caused a series of interacting effects including global warming, altered oceanic circulation and heat transfer, anoxia, and changes in $\mathrm{S}, \mathrm{C}$, and $\mathrm{N}$ isotopic ratios, reflecting global perturbations in cycling.

Although eruption of the Siberian Traps is inferred to have triggered the cascading events leading to the Late Permian hothouse and massive end Permian extinction (e.g., Shen et al., 2011), the age of the Lamping Peak forests is too poorly constrained to link them temporally to the rapidly extruded Siberian flood basalts (Reichow et al., 2009). Their occurrence at the top of the Lamping Peak section makes estimating their position relative to the top of the Buckley Formation and Permian - Triassic boundary speculative, and an unknown thickness of Buckley Formation may have been removed by pre-Triassic erosion.

Given that the necessary greenhouse conditions were in place, polar warming alternatively could have been initiated by eruption of the Emshian flood basalts in China which terminated about 8 million years prior to the Siberian Traps 
(Zhong et al., 2014) and which have been implicated in the Capitanian extinction event (Bond et al., 2010).

\section{Conclusions}

Two closely spaced bedding planes in the Permian Buckley Formation contain a large number of in situ stumps reflecting Glossopteris forests growing at high southern paleolatitude during the Permian. The forests had a high number of stems per hectare, stems large enough to support tree heights of up to $19 \mathrm{~m}$. Basal areas of LP1 and LP2 can be calculated with a high degree of certainty, and they were large compared to modern and other ancient forests. Estimating biomass and productivity (ANPP; biomass added per year) involves uncertainties, and thus can be only broadly constrained. However, bracketed calculated values of ANPP in conjunction with high basal areas and high estimated biomass are consistent with these forests being as productive as most modern forests at any latitude and more productive than many younger high latitude fossil forests. LP1 and LP2 fossil forests confirm that hothouse conditions were extant in the Late Permian and were established before the extrusion of the Siberian flood basalts at the end of Permian that triggered extreme global warming, and changes in ocean currents and heat transfer with deleterious consequences leading to the end-Permian extinction.

\section{Acknowledgements}

Supported by grants from the United States National Science Foundation, ANT 0126146 and OPP 0440954 to MFM and ANT 0126086 and PLR 0943935 to JLI. We thank Peter Flaig for assistance with fieldwork and for Figure 2. Michael Huston gave valuable advice about modern forests and provided his original diagram that 
served as the basis for Figure 8. Vanessa Bowman, Paul McCarthy, and an anonymous reviewer made valuable suggestions on an earlier version of this manuscript. Mary Parrish of the National Museum of Natural History, Smithsonian Institute produced Figure 9.

\section{References}

Barrett, P.J., Elliot, D.H., Lindsay, J.F., 1986. The Beacon Supergroup (DevonianTriassic) and Ferrar Group (Jurassic) in the Beardmore Glacier area, Antarctica: Geology of the Central Transantarctic Mountains. Antarctic Research Series 36, $339-428$.

Basinger, J.F., Greenwood, D.G., Sweda., T., 1994. Early Tertiary vegetation of Arctic Canada and its relevance to paleoclimatic interpretation. Nato ASI Series, Series I, Global Environmental Change 27, 175-198.

BenHua, F., Hui, G., Zuolong, D., 2000, Study on wood density and chemistry components of Ginkgo biloba. Journal of Northeast Forestry University 28(4), p. 47-49.

Bond, D.P.G., Hilton, J., Wignall, P.B., Ali, J.R., Stevens, L.G., Sun, Y., Lai, X., 2010. The Middle Permian (Capitanian) mass extinction on land and in the oceans. EarthScience Reviews 102, 100-116.

Brown, S., 1981. A comparison of the structure, primary productivity, and transpiration of Cypress Ecosystems in Florida. Ecological Monographs 51(4), 403-427. 
Busing, R.T., Fujimori, T., 2005. Biomass, production and woody detritus in an old coast redwood (Sequoia sempervirens) forest. Plant Ecology 177, 177-188.

Cantrill, D.J., Poole, I., 2012. The Vegetation of Antarctica through Geological Time. Cambridge University Press, Cambridge, UK 480p.

Collinson, J.W., Isbell, J.L., Elliot, D.H., Miller, M.F., Miller, J.M.G., 1994. PermianTriassic Transantarctic Basin, in: Veevers, J.J., Powell, C.McA. (Eds.), PermianTriassic Pangean Basins and Foldbelts along the Panthalassan Margin of Gondwanaland. Geological Society of America Memoir 184, 173-222.

Cottam, G., Curtis, J.T., 1956. The use of distance measures in phytosociological sampling. Ecology 37, 451-460.

Creber, G.T., Chaloner, W.G., 1984. Influence of environmental factors on the wood structure of living and fossil trees. Botanical Review 50, 357-448.

Creber, G.T., Chaloner, W.G., 1985. Tree growth in the Mesozoic and early Tertiary and the reconstruction of paleoclimates. Palaeogeography, Palaeoclimatology, Palaeoecology 52, 35-60.

Cúneo, N.R., 1996. Permian phytogeography in Gondwana. Palaeogeography, Palaeoclimatology, Palaeoecology 125, 75-104.

Cúneo, N.R., Isbell, J., Taylor, E.L., Taylor, T.N., 1993. The Glossopteris flora from Antarctica: taphonomy and paleoecology. 12 Congres International de Geologie du Carbonifere-Permian, Buenos Aires. Comptes Rendus 2, 13-40.

Cúneo, N.R., Taylor, E.L., Taylor, T.N., Krings, M., 2003. In situ fossil forest from the upper Fremouw Formation (Triassic) of Antarctica: paleoenvironmental setting 
and paleoclimate analysis. Palaeogeography, Palaeoclimatology, Palaeoecology $197,239-261$.

Decombeix, A.-L., 2010. Understanding the biology of high-latitude trees in a greenhouse world. Palaios, 25, 423-435.

DiMichele, W.A., Falcon-Lang, H.J., 2011. Pennsylvania 'fossil forests" in growth potion (To assemblages): origin, taphonomic bias and paleoecological insights. Journal of the Geological Society, London 168, 585-605.

Dixon, W.J., Massey, F.J., Jr., 1969. Introduction to Statistical Analysis, $3^{\text {rd }}$ ed. McGraw Hill, New York.

Falcon-Lang, H.J., Cantrill, D.J., Nichols, F.J., 2001. Biodiversity and terrestrial ecology of a mid-Cretaceous, high latitude floodplain, Alexander Island, Antarctica. Journal of the Geological Society of London 158. 709-724.

Flaig, P.P., 2005. Changing fluvial style across the Permian-Triassic boundary: Beardmore Glacier region, Central Transantarctic Mountains, Antarctica. Unpublished M.S. Thesis, University of Wisconsin, Milwaukee. Milwaukee,WI.

Francis, J.E., 1991. The dynamics of polar fossil forests: Tertiary fossil forests of Axel Heiberg Island, Canadian Arctic Archipelago. Geological Survey of Canada Bulletin 403, 469-481.

Francis, J.E., Woolfe, K.J., Arnott, M.J., Barrett, P.J., 1993. Permian forests of Allan Hills, Antarctica: the paleoclimate of Gondwanan high latitudes. Special Papers in Paleontology 49, 75-83. 
Francis, J.E., Woolfe, K.J., Arnot, M.J., Barrett, P.J., 1994. Permian climates of the southern margins of Pangea: evidence from fossil wood in Antarctica. In Embry, A.F., Beauchamp, B., Glass, D.J. (Eds.), Pangea: Global Environments and Resources. Canadian Society of Petroleum Geologists Memoir, 17, 275-282.

Gholz, H.L., 1982, Environmental limits on above ground net primary production, leaf area, and biomass in vegetation zones of the Pacific NW. Ecology 63, 469481.

Greenwood, D.R., Basinger, J.F., 1994. The paleoecology of high-latitude Eocene swamp forests frp, Ace; Heiberg Island, Canadian High Arctic. Review of Paleobotany and Palynology 81, 83-97.

Gulbranson, E.L., Isbell, J.L., Taylor, E.L., Ryberg, P. E., Taylor, T.N., 2012. Permian polar forests: deciduousness and environmental variation. Geobiology 10, 479-495.

Gulbranson, E.L., Ryberg, P.E., Decombeix, A-L., Taylor, E.L., Taylor, T.N., Isbell, J.L., 2014. Leaf habit of Late Permian Glossopteris trees from high-paleolatitude forests. Journal of the Geological Society of London 171, 493-507.

Huston, M.A., Wolverton, S. 2009. The global distribution of net primary production: resolving the Paradox. Ecological Monographs 79(3), 343-377.

Isbell, J.L., 1990. Fluvial sedimentology and basin analyses of the Permian Fairchild and Buckley Formations, Beardmore Glacier region, and the Weller Coal 
Measures, southern Victoria Land, Antarctica. Unpublished PhD dissertation, The Ohio State University, Columbus, OH USA, 377p.

Isbell, J. L., Seegers, G. M., and Gelhar, G. A., 1997, Upper Paleozoic glacial and postglacial deposits, central Transantarctic Mountains, Antarctica. in Martini, I. P., ed., Late Glacial and Postglacial Environmental Changes: Quaternary, Carboniferous-Permian, and Proterozoic: Oxford, U.K., Oxford University Press, $230-242$.

Isbell, J.L., Miller, M.F., Babcock, L.E., Hasiotis, S.ET., Ice-marginal environments and ecosystem prior to initial advance of the late Paleozoic ice sheet in the Mount Butters area of the central Transantarctic Mountains, Antarctica.

Sedimentology 48, 953-970. 2001

Isbell, J.L., Koch, Z.J., Szablewski, G.M., Lenaker, P.A., 2008. Permian glacigenic deposits in the Transantarctic Mountains, Antarctica: in Fielding, C.R., Frank, T.D., Isbell, J.L. (Eds.) Resolving the Late Paleozoic Ice Age in Time and Space, Geological Society of America Special Paper 441, 59-70.

Isbell, J.L., Henry, L.C., Gulbranson. E.L., Limarino, CO., Fraiser, M.L., Koch, Z.L., Ciccioli, P.L., Dineen, A.A., 2012. Evaluation of glacial paradoxes during the late Paleozoic ice age using the concept of the equilibrium line altitude (ELA) as a control on glaciation. Gondwana Research 22, 1-9.

Jefferson, T.H., 1982. Fossil forests from the Lower Cretaceous of Alexander Island, Antarctica. Palaeontology 25, 681-708.

Joachimski, M.M., Lai, X., Shen, S., Jiang, H., Luo, G., Chen, B., Sun, Y., 2012. Climate 
warming in the latest Permian and the Permian-Triassic mass extinction. Geology 40(3), 195-198.

Kidder, D. L., Worsley, T.R., 2004. Causes and consequences of extreme PermoTriassic warming to globally equable climate and relation to the PermoTriassic extinction and recovery. Palaeogeography, Palaeoclimatology, Palaeoecology 203, 207-237.

Kidder, D.L., Worsley, T.R., 2010. Phanerozoic Large Igneous Provinces (LIPs), HEATT (Haline Euxinic Acidic Thermal Transgression) episodes, and mass extinctions. Palaeogeography, Palaeoclimatology, Palaeoecology 295, 162-191.

Knepprath, N. E., 2006. Late Permian forests of the Buckley Formation, Beardmore Glacier area, Antarctica. Unpublished M.S. Thesis, Vanderbilt University, Nashville, TN USA, 80p.

Lawver, L.A., Dalziel, I.W.D., Norton, I.O., Gahagan, L.M., 2008. The Plates 2007 Atlas of Plate Reconstructions (750Ma to Present Day), Plates Progress Report No. 305-0307, University of Texas Technical Report No. 195, 160p.

Megonigal, J.P., Conner, W.H., Kroeger, S., and Sharitz, R.R., 1997. Aboveground production in southeastern floodplain forests: a test of the subsidy-stress hypothesis. Ecology 78(2), 370-384.

Miller, G.H., Brigham-Grette, J., Alley, R.B., Anderson, L., Bauch, H.A. and 18 others. 2010. Temperature and precipitation history of the Arctic. Quaternary Science Reviews 29, 1679-1715.

Miller, M.F., Isbell, J.L., 2010. Reconstruction of a high-latitude, post-glacial lake; 
Mackellar Formation (Permian) of Antarctica. Geological Society of America Special Paper 468, 193-207.

Montañez, I.P., Tabor, N.J., Niemeier, D. and others, 2007. CO2-forced climate and vegetation instability during late Paleozoic deglaciation. Science 325, 87-91.

Montañez, I,P., Poulsen, C.J., 2013. The Late Paleozoic ice age: an evolving paradigm. Annual Review of Earth and Planetary Sciences 41, 629-656.

Mossbrugger, V., Gee, C.T., Belz, F., Ashraf, A.R., 1994. Three-dimensional reconstruction of an in-situ Miocene peat forest from the Lower Rhine Embayment, northwestern Germany - new methods in palaeovegetational analysis. Palaeogeography, Palaeoclimatology, Palaeoecology 110, 295-317.

Niklas, K.J., 1994. Predicting the height of fossil plant remains - an allometric approach to an old problem. American Journal of Botany 81, 1235-1242.

Opalinski, B., Cowling, S.A., 2013. Using carbon economics of tree height to estimate evolutionary timing of cold tolerance in conifers. Palaeogeography, Palaeoclimatology, Palaeoecology 392, 495-501.

Osborne, C.P., Beerling, D.J., 2002. Sensitivity of tree growth to a high CO2 environment: consequences for interpreting the characteristics of fossil woods from ancient "greenhouse" worlds. Palaeogeography, Palaeoclimatology, Palaeoecology 182, 15-29.

Parrish, J.T., Spicer, R.A., 1988. Middle Cretaceous wood from the Nanushuk Group, 
central North Slope, Alaska. Palaeontology 34, 19-34.

Pigg, K.B., Taylor, T.N., 1993. Anatomically preserved Glossopteris stems with attached leaves from the Central Transantarctic Mountains, Antarctica. American Journal of Botany 80, 500-516.

Pole, M., 1999. Structure of a near-polar latitude forest from the New Zealand Jurassic. Palaeogeography, Palaeoclimatology, Palaeoecology 147, 121-139.

Powell, C.M., Li, Z.X., 1994. Reconstruction of the Panthalassan margin of Gondwanaland: Veevers, J.J. , Powell, C.McA. (Eds.), Permian-Triassic Pangean Basins and Foldbelts along the Panthalassan Margin of Gondwanaland. Geological Society of America Memoir 184, 5-9.

Reichow, M.K., Pringle, M.S., Al'Mukhamedov, A.I., and 13 others, 2009. The timing and extent of the eruption of the Siberian Traps large igneous province: implications for the end-Permian environmental crisis. Earth and Planetary Science Letters 277, 9-20.

Rößler, R., Zierold, T., Feng, Z., Kretzschmar, R., Merbitz, M., Annacker, A., and Schneider, J.W., 2012. A snapshot of an early Permian ecosystem preserved by explosive volcanism: new results from the Chemnitz petrified forest, Germany. Palaios 27, 814-834.

Royer, D.L., Berner, R.A., Montanez, I.P., Tabor, N.J., Beerling, D.J., 2004. CO² as a primary driver of Phanerozoic climate. GSA Today 14(3), 4-10. 
Ryberg,P.E., Taylor, E.L. 2013. Lonchiphyllum aplospermum sp. Nov.: an anatomically preserved glossopterid megasporphyll from the Upper Permian of Skaar Ridge, Transantarctic Mountains, Antarctica. International Journal of Plant Sciences 174, 396-405.

Shen, S.Z., Crowley, J.L., Wang, Y. and 19 others, 2011. Calibrating the end-Permian mass extinction. Science 334, 1367-1372.

Shi, G.R., Waterhouse, J.B., 2010. Late Paleozoic global changes affecting highlatitude environments and biotas: an introduction. Palaeogeography, Palaeoclimatology, Palaeoecology 298, 1-16.

Schlesinger, W.H. 1978. Community structure, dynamics and nutrient cycling in the Okefenokee cypress swamp forest. Ecological Monographs 48, 43-65.

Singh, S.P., Bhupendra, S.A., Zobel, D.B., 1994. Biomass, productivity, leaf longevity, and forest structure in the Central Himalaya. Ecological Monographs 64, 401421.

Spicer, R.A., Chapman, J.L., 1990. Climate change and the evolution of high-latitude terrestrial vegetation and floras. Trends in Ecology and Evolution 5, 279-284.

Spicer, R.A., Herman, A.B., 2010. The Late Cretaceous environment of the Arctic: a quantitative reassessment based on fossil plants. Palaeogeography, Palaeoclimatology, Palaeoecology 295, 423-442.

Taggart, R.E., Cross, A.T., 2009. Global greenhouse to ice house and back again: the origin and future of the Boreal Forest bionome. Global and Planetary Change 
65, 115-121.

Taylor, E.L., Taylor, T.N., Isbell, J.L., 1997. Evidence of Permian forests from the Shackleton Glacier area, Antarctica. American Journal of Botany 84 (6, suppl.), 143.

Taylor, E.L., Ryberg, P.E., 2007. Tree growth at polar latitudes based on fossil tree ring analysis. Palaeogeography, Palaeoclimatology, Palaeoecology 255, 246264.

Taylor, E.L., Taylor, T.N., Cúneo, N.R., 1992. The present is not the key to the past: a polar forest from the Permian of Antarctica. Science 257, 1675-1677.

Taylor, E.L., Taylor, T.N., Cúneo, N.R., 2000. Permian and Triassic high latitude paleoclimates: evidence from fossil biotas. In Huberm B.T., MacLeod, K.G., Wind, S,L. (Eds,), Warm Climates in Earth History. Cambridge Univ. Press, Cambridge, UK, pp. 321-350.

Thorn, V., 2005. A Middle Jurassic forest in New Zealand. Palaeontology 48(5), 1021-1039.

Weaver, L.S., McLoughlin, S., Drinnan, A.N., 1997. Fossil woods from the Permian Bainmedart Coal Measures, northern Prince Charles Mountains, East Antarctica. Australian Geological Survey Organisation Journal of Geology and Geophysics 16, 655-676.

Williams, C.J., 2007. High latitude forest structure: methodological considerations 
and insights on reconstructing high-latitude fossil forests. Bulletin of the Peabody Museum of Natural History 48(2), 339-357.

Williams, C.J., Johnson, A.H., LePage, B.A., Vann, D.R., Sweda, T., 2003. Reconstruction of Teritary Metasequoia forests. II. Structure, biomass, and productivity of Eocene floodplain forests in the Canadian Arctic. Paleobiology $29,238-274$.

Williams, C.J., Mendell, E.K., Murphy, J., Court, W.M., Johnson, A.H., and Richter, S.L., 2008. Paleoenvironmental reconstruction of a middle Miocene forest from the western Canadian Arctic. Palaeogeography, Palaeoclimatology, Palaeoecology $261,160-176$.

Williams, C.J., LePage, B.A., Johnson, A.H., Vann, D.R., 2009. Structure, biomass, and productivity of a late Paleocene arctic forest. Proceedings of the Academy of Natural Sciences of Philadelphia 158, 107-127.

Williams, C.J., Trostle, K.D., Sunderlin, D., 2010. Fossil wood in coal-forming environments of the late Paleocene-early Eocene Chickaloon Formation. Palaeogeography, Palaeoclimatology, Palaeoecology 295, 363-375.

Yoon, T.K., Park, C-W., Lee, S.J., Ko, S., Kim, K.N., Son, Y., Lee, K.H., Oh, S., Lee, W-K., Son, Y., 2013, Allometric equations for estimating the aboveground volume of five common urban street tree species in Daegu, Korea. Urban Forestry and Urban Greening 12, 344-349. 
Zhong, Y-T., He, B., Mundil, R., Xu, Y-G., 2014. CA-TIMS zircon U-PB dating of felsic ignimbrite from the Binchuan section: implications for the termination age of Emeishan large igneous province. Lithos 204, 14-19.

\section{Figure Captions}

Fig. 1. Location of Lamping Peak (S 84⒓6"; E $164^{\circ} 40.7^{\prime \prime}$ ) site of large Permian fossil forests (LP1 and LP2) in the Beardmore Glacier area, Central Transantarctic Mountains.

Fig. 2. Stratigraphic section of the Buckley Formation at Lamping Peak (from Knepprath, 2006). The two horizons with fossil forests (LP1 and LP2) occur near the top of the section.

Fig. 3. Photo taken from helicopter of the $55 \mathrm{~m}$ thick section of Buckley Formation exposed at Lamping Peak (see Fig. 2). The beds are flat lying and extensive bedding plane exposures, including those with LP1 and LP2 fossil forests occur near the top of the section. A dolerite sill and small dike (Ferrar Dolerite) that intruded the Buckley Formation during the Jurassic are exposed at the base of the section.

Fig. 4. A. Stump in LP2 with shallow roots extending outward. Wood has been replaced with the mineral magnetite, probably formed by hydrothermal fluids generated during Jurassic emplacement Ferrar Dolerite (Fig. 3). Scale beneath left

root is $15 \mathrm{~cm}$ long. B. Stump with shallow roots extending outward as in Fig. 4a, but with features outlined. Scale as in Fig. 4a.

Fig. 5. Map of trees of different sizes (diameter at ground level; DGL) in LP1 and LP2 fossil forests. 
Fig. 6. A. Frequency distributions of stump diameters in LP1 $(\mathrm{N}=53)$ and LP2 $(\mathrm{n}=21)$ fossil forests, both composed of Glossopteris-bearing trees. B. Schematic size frequency distributions of even and uneven age monospecific forests (modified from Williams, 2007, Figure 1).

Fig. 7. A. Basal area vs. biomass for Lamping Peak forests and selected modern forests. Sources in supplemental information. The Lamping Peak biomass estimates plotted here were made using the allometric equation for Ginkgo biloba (Yoon et al., 2013) and wood density of G. biloba (BenHua et al., 2000). B. Basal area vs. biomass for Lamping Peak fossil forests and selected modern forests as in Fig. 7a, but with change of scale, removing 3 of the high basal area, high biomass US (Pacific NW) conifer forests. Note that the tropical forests have a trend toward higher biomass:basal area ratio than other the other forests. Key as in Fig. 7a. C. Basal area vs. biomass for Lamping Peak fossil forests and selected modern forests as in Fig. 7a and $b$ with bracketed estimate of Lamping Peak biomasses, estimated by extrapolating trend of many modern forests (excluding tropical forests and US [Pacific NW] conifer forests) to include the Lamping Peak forest basal areas. Key as in Fig. 7a.

Fig. 8. Basal areas measured in over 800 modern mature forests around the world by $10^{\circ}$ latitude zones showing mean (thick black vertical bar) and SD on either side of mean. The gray band represents the range of basal areas of the Permian Lamping Peak forests. LP1 and LP2 basal areas exceed the mean basal areas of forests at all latitudes. (From Huston and Wolverton, 2009, Figure 7, modified by addition of range of LP1 and LP2 forests.) 
Fig. 9. Reconstruction of Lamping Peak forests based on distribution, diameter, and estimated height of trees (by Mary Parrish, Smithsonian Institution, National Museum of Natural History).

\section{Table Captions}

Table 1. Characteristics of Lamping Peak forests and their structure.

Table 2. Estimates of Annual Net Primary Productivity (biomass produced each year) and eNPP (biomass produced monthly during growing season) for Lamping Peak 1 and 2 forests. Values vary based on which estimates of biomass, and of tree ages, as determined by the measure of tree ring thickness (mean, minimum, maximum, from Taylor and Ryberg, 2007) that are applied, and, for eNPP, the estimate of duration of growing season.

Table 3. Characteristics of high latitude Permian forests preserved in the Buckley Formation in the Beardmore Glacier area. All fossil forests are within $100 \mathrm{~km}$ of Lamping Peak (LP1, LP2).

Table 4. Characteristics of selected high latitude fossil forests, modified from Williams (2007). 


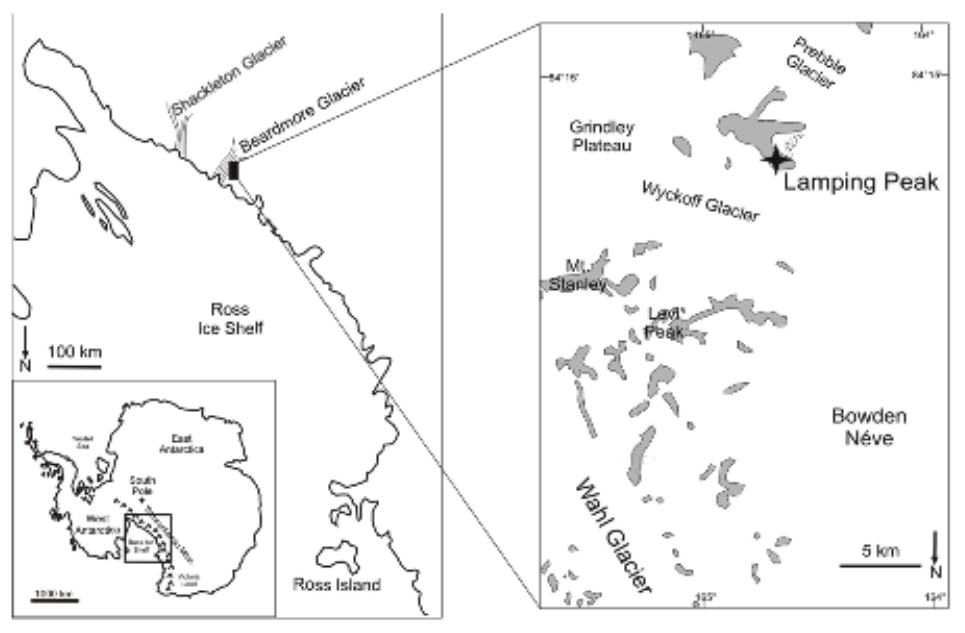




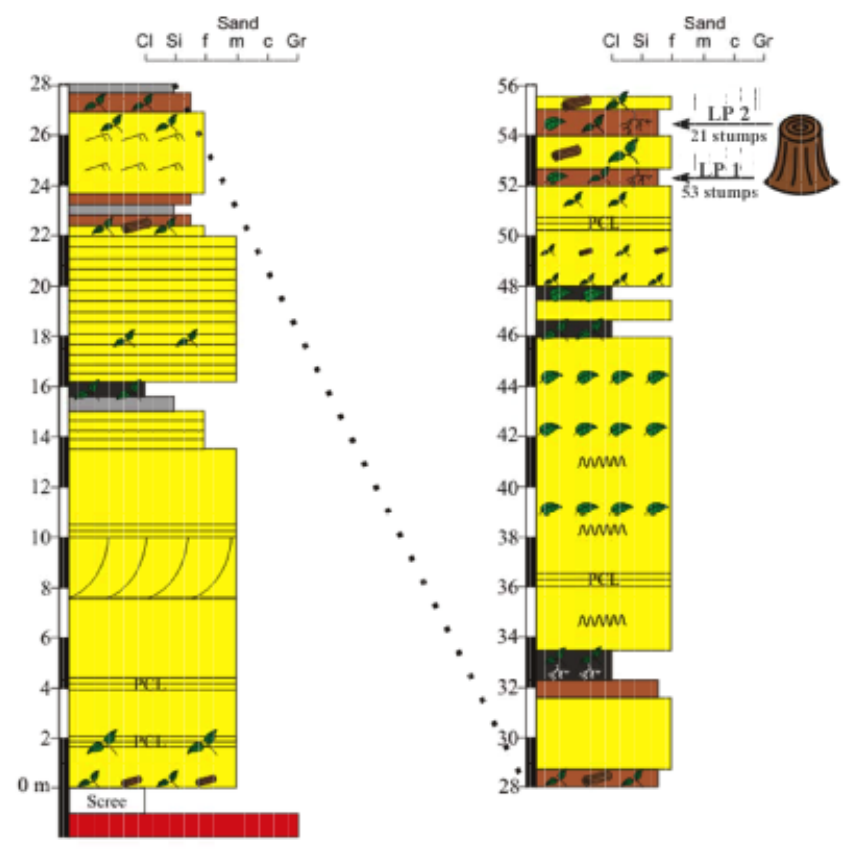

\begin{tabular}{ll}
\hline & Sandstone \\
Laminated sandstone \\
Siltstone \\
Shale (carbonaceous) \\
Paleosol \\
\hline
\end{tabular}




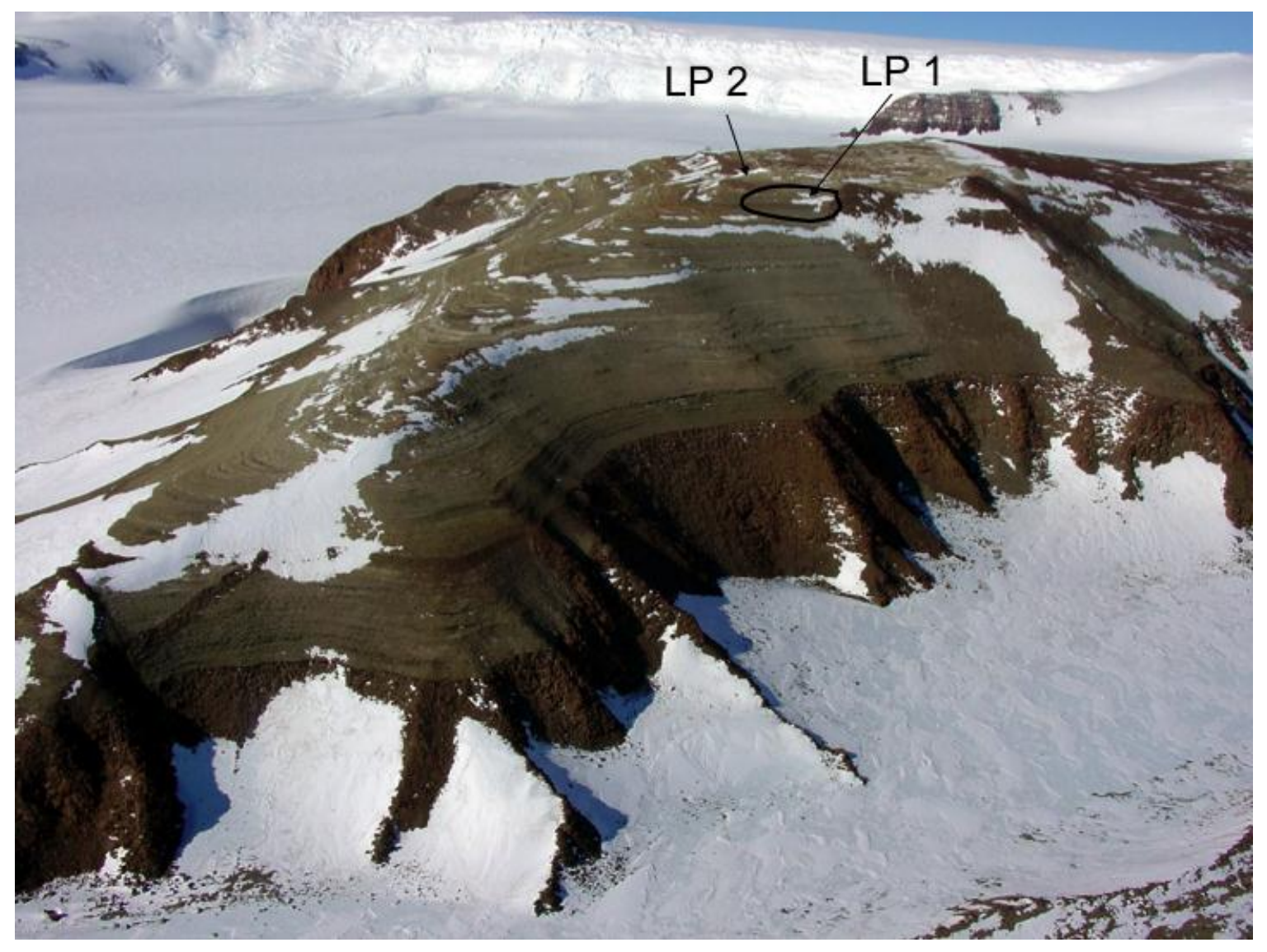




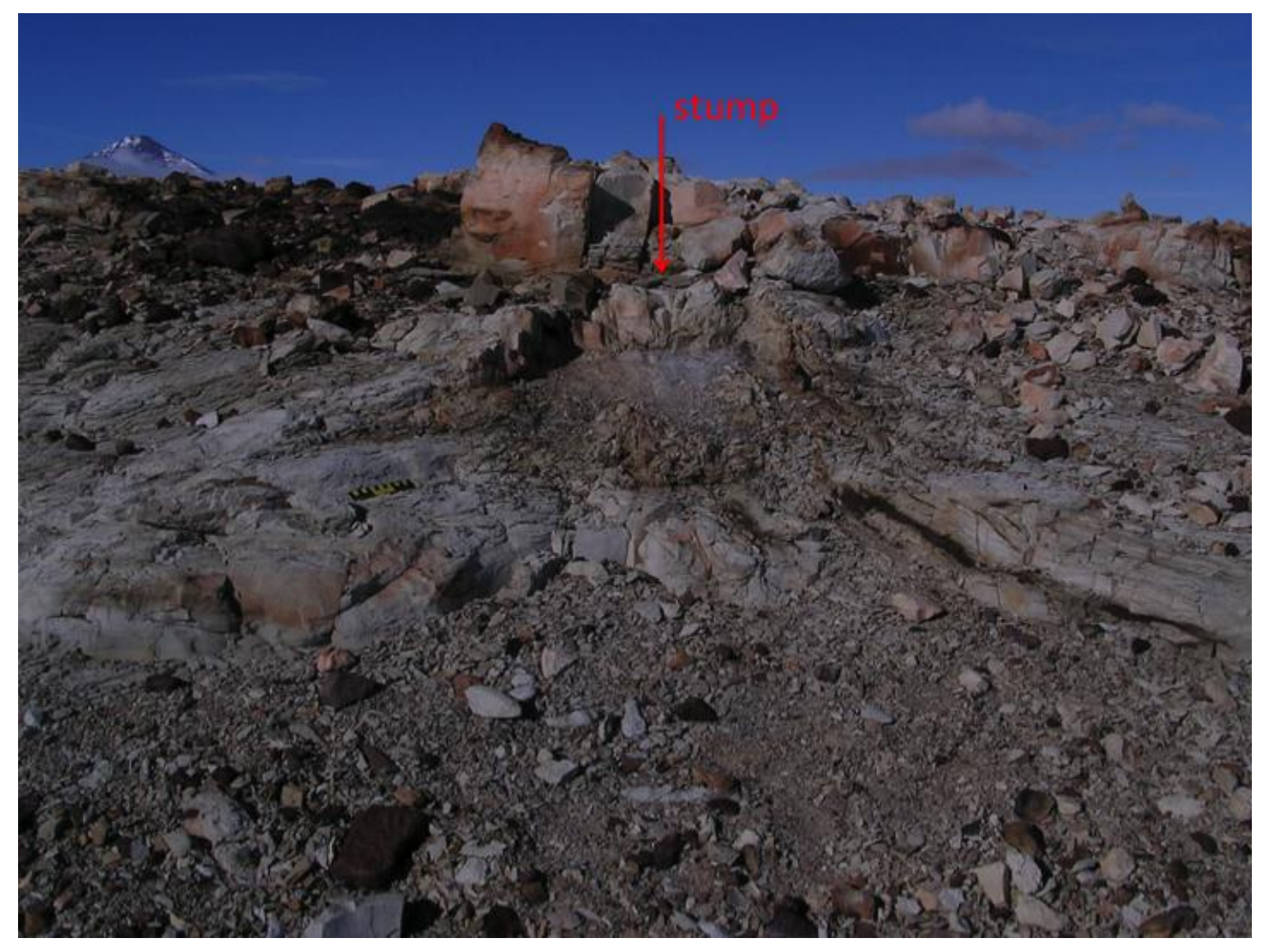




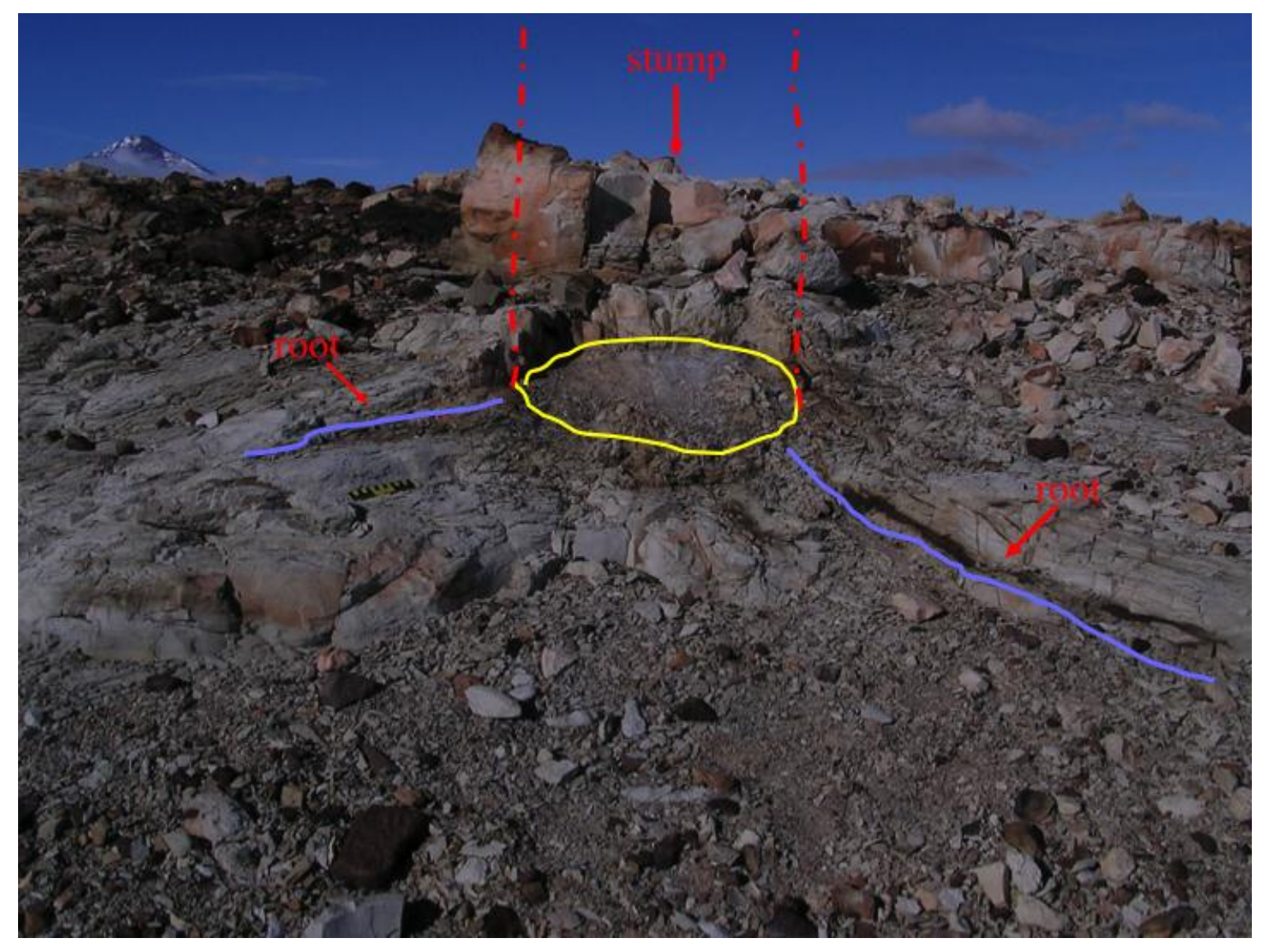


- $1-16 \mathrm{~cm}$ small

- $17-32 \mathrm{~cm}$ medium

- 33-48 cm large

- $49-75 \mathrm{~cm}$ very large
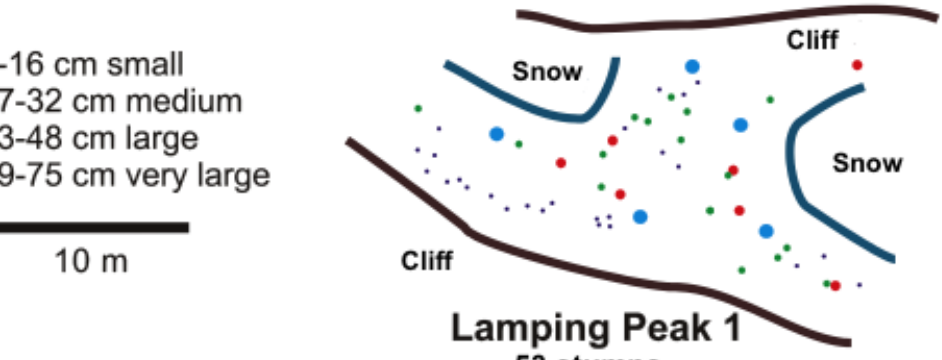
53 stumps



21 stumps 

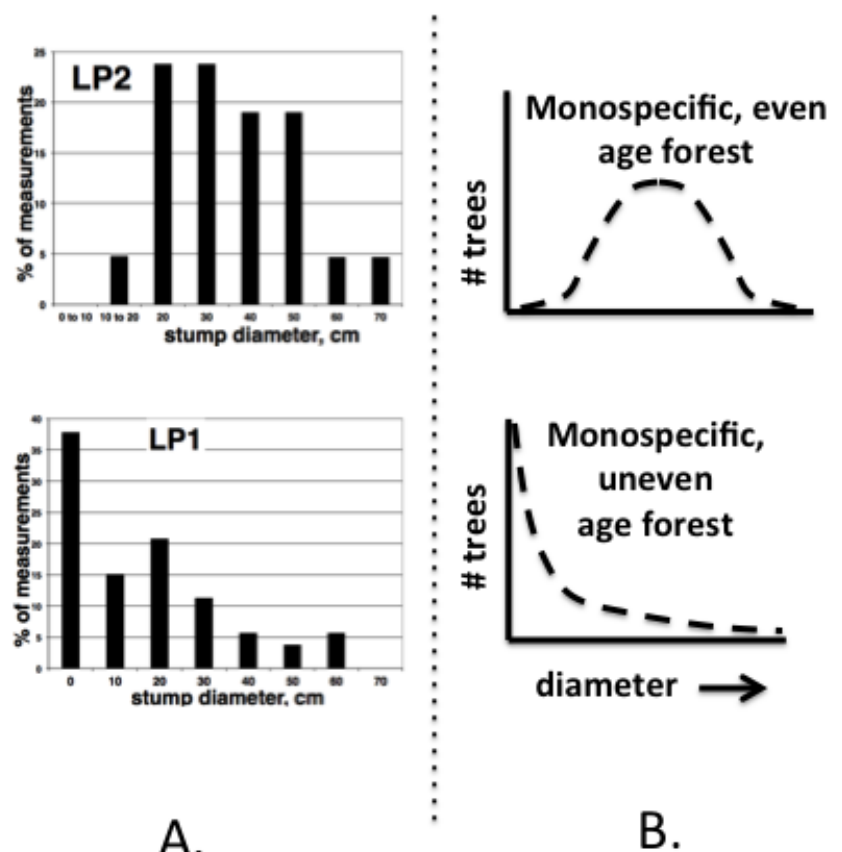

A.

B. 


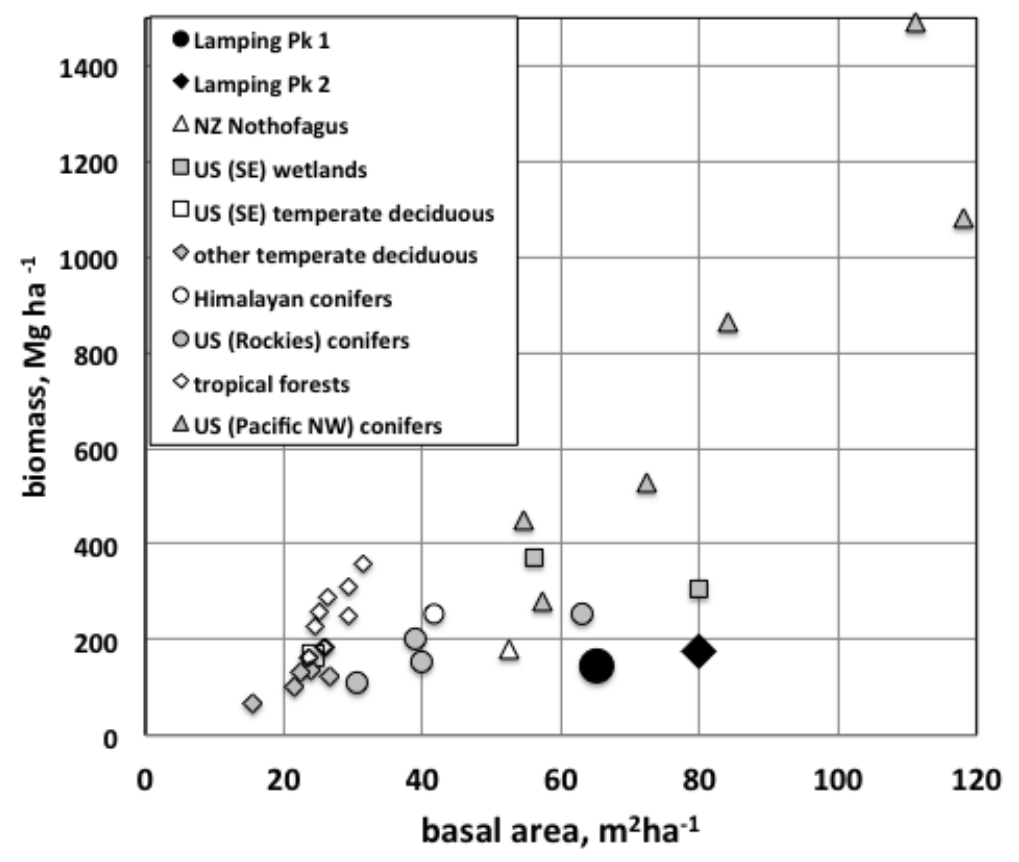




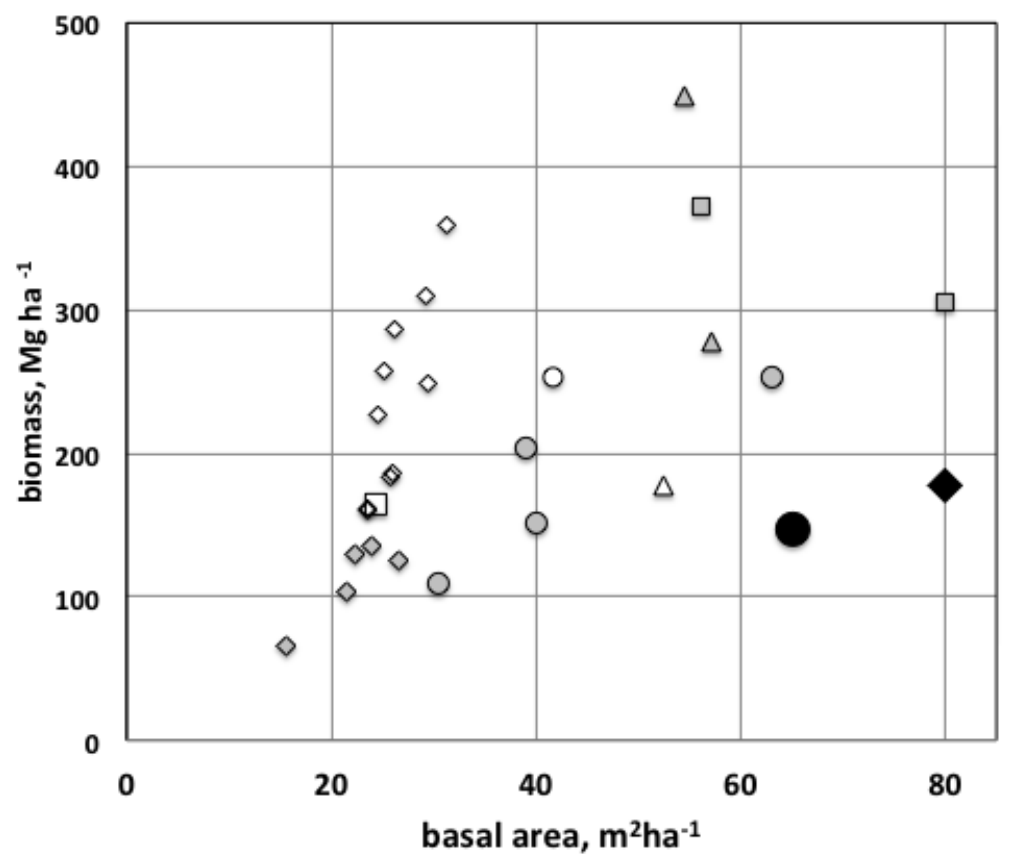




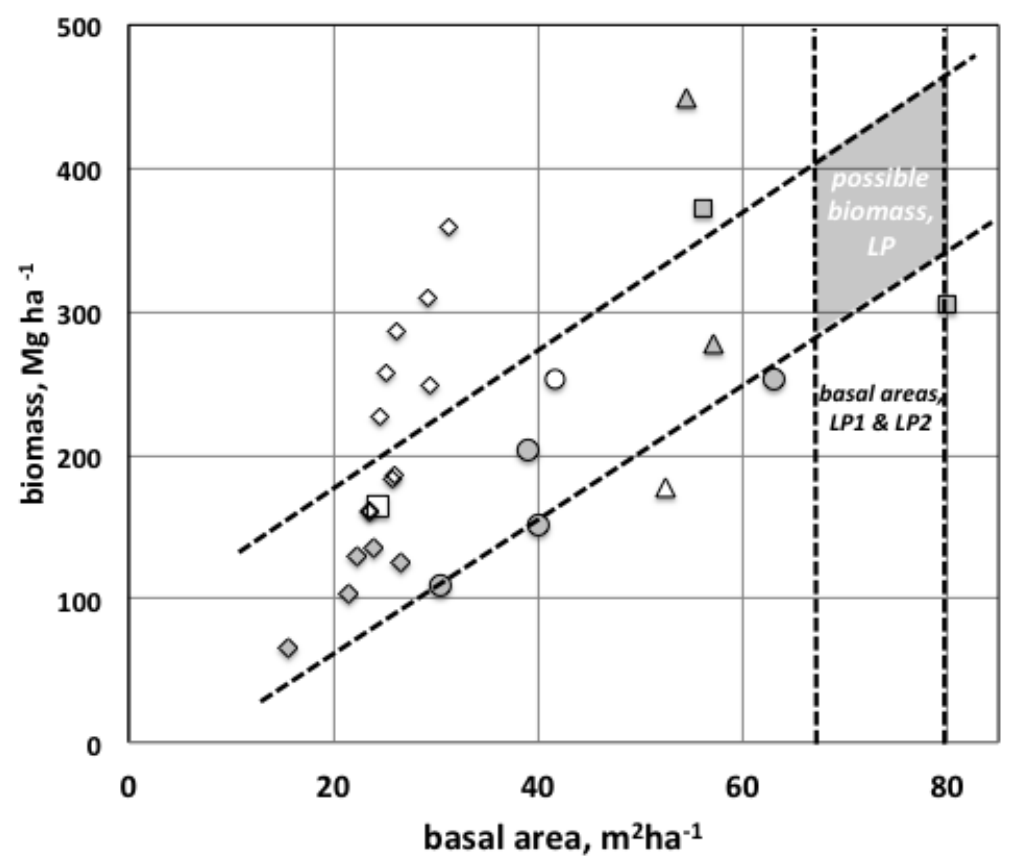




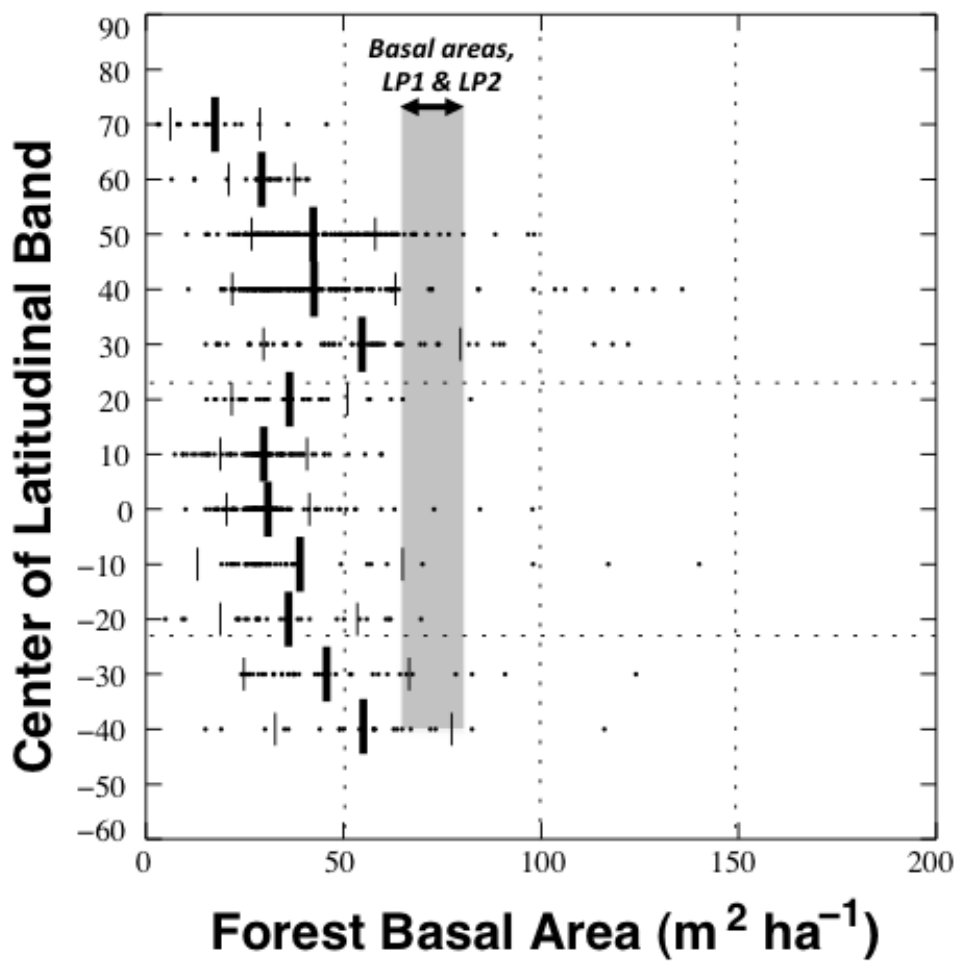




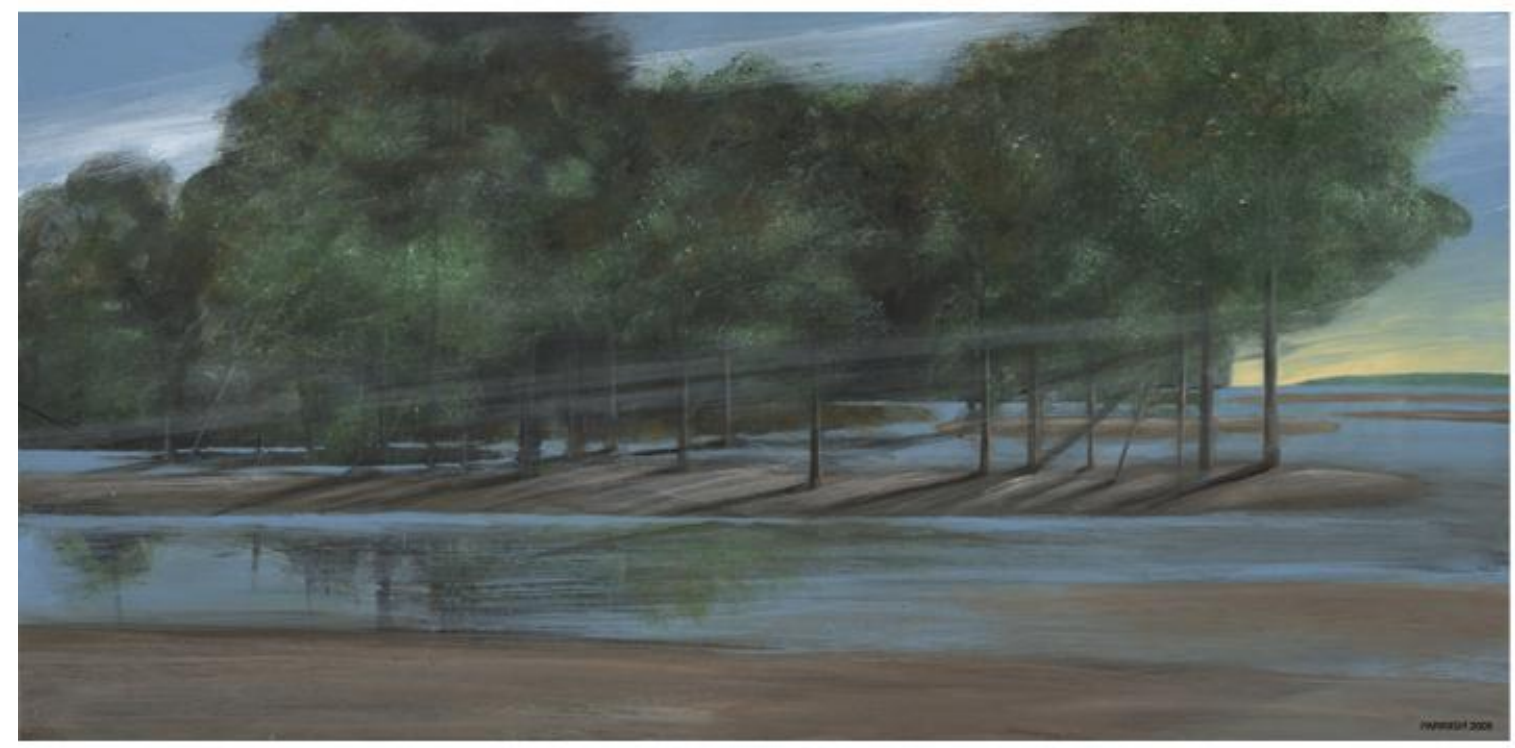




\begin{tabular}{|c|c|c|}
\hline & LP 1 & LP 2 \\
\hline Number of stumps & 53 & 21 \\
\hline $\begin{array}{l}\text { Mean diameter (DGL) } \\
\text { (cm) }\end{array}$ & $20.9(\sigma=17.1)$ & $39.2(\sigma=17.1)$ \\
\hline $\begin{array}{l}\text { Mean maximum height } \\
\text { Based on DGL (m) }\end{array}$ & $15.4(\sigma=8.5)$ & $24.6(\sigma=5.0)$ \\
\hline $\begin{array}{l}\text { Mean diameter (DBH) } \\
(\mathrm{cm})\end{array}$ & $13.5(\sigma=10.4)$ & $24.7(\sigma=8.5)$ \\
\hline $\begin{array}{l}\text { Mean maximum height } \\
\text { Based on DBH (m) }\end{array}$ & $11.7(\sigma=6.7)$ & $18.9(\sigma=4.0)$ \\
\hline $\begin{array}{l}\text { Stand density } \\
\text { (trees ha-1) }\end{array}$ & 2505 & 1185 \\
\hline Basal area (DGL) $\left(\mathrm{m}^{2} \mathrm{ha}^{-1}\right)$ & 173 & 194 \\
\hline Basal area (DBH) $\left(\mathrm{m}^{2} \mathrm{ha}^{-1}\right)$ & 65 & 80 \\
\hline Age of trees (years) & $29.5(16.5-75)$ & $54.5(30.5-137.5)$ \\
\hline $\begin{array}{l}\text { Biomass (above ground) } \\
{\text { (Mg ha-1 }{ }^{-1} \text { based on wood }}_{\text {density and allometric }} \\
\text { equations for Ginkgo } \\
\text { biloba }\end{array}$ & 146.5 & 177.5 \\
\hline $\begin{array}{l}\text { Biomass (above ground) } \\
\left(\mathrm{Mg} \mathrm{ha}^{-1}\right) \text { estimated from } \\
\text { biomass of modern forests } \\
\text { with similar basal areas }\end{array}$ & $225-340$ & $290-400$ \\
\hline $\begin{array}{l}\text { Annual Net Primary } \\
\text { Productivity (ANPP) } \\
\text { biomass (above ground) } \\
\text { produced yearly ( } \mathrm{g} \mathrm{m}^{-2} \mathrm{yr}^{-} \\
\text {1) }\end{array}$ & $105-2060$ & $109-1310$ \\
\hline
\end{tabular}

1. Values indicate range, based on mean, minimum, and mean maximum thickness of growth lines in permineralized wood from the (Permian) Buckley Formation primarily from Skaar Ridge located $\sim 100 \mathrm{~km}$ from Lamping Peak (Taylor and Ryberg, 2007).

Table 1: Characteristics of Lamping Peak forests and their structure. 


\begin{tabular}{|c|c|c|c|c|c|c|c|c|}
\hline & & \multicolumn{3}{|c|}{ ANPP } & \multicolumn{4}{|c|}{ eNPP4. } \\
\hline & $\begin{array}{l}\text { Source of } \\
\text { biomass estimate }\end{array}$ & $\begin{array}{l}\mathrm{g} \mathrm{m}^{-2} \mathrm{yr}^{-1} \\
\left(\text { mean }^{2}\right)\end{array}$ & $\begin{array}{c}\mathrm{g} \mathrm{m}^{-2} \mathrm{yr}^{-1} \\
\left(\text { minimum }{ }^{2}\right)\end{array}$ & $\begin{array}{c}\mathrm{g} \mathrm{m}^{-2} \mathrm{yr}^{-1} \\
\left(\text { maximum }{ }^{2}\right)\end{array}$ & $\begin{array}{c}\mathrm{g} \mathrm{m}^{-2} \text { month }^{-1} \\
3 \text { month } \\
\left(\text { mean }^{2}\right)\end{array}$ & $\begin{array}{c}\mathrm{g} \mathrm{m}^{-2} \text { month }^{-1} \\
7 \text { month } \\
\left(\text { mean }^{2}\right)\end{array}$ & $\begin{array}{l}\mathrm{g} \mathrm{m}^{-2} \text { month }^{-1} \\
3 \text { month } \\
\text { (minimum }^{2} \text { ) }\end{array}$ & $\begin{array}{r}\mathrm{g} \mathrm{m}^{-2} \\
7 \mathrm{~m} \\
(\text { mini }\end{array}$ \\
\hline \multirow[t]{3}{*}{ LP1 } & $\begin{array}{l}\text { Allometric } \\
\text { equation for } \\
\text { Ginkgo biloba }^{1} \text {. }\end{array}$ & 263 & 105 & 468 & 88 & 388 & 35 & \\
\hline & $\begin{array}{l}225 \mathrm{Mg} \mathrm{ha}^{-1} \\
(\text { Fig. } 7 \mathrm{c})^{3 .}\end{array}$ & 763 & 300 & 1364 & 254 & 109 & 100 & \\
\hline & $\begin{array}{l}340 \mathrm{Mg} \mathrm{ha}^{-1} \\
(\text { Fig. } 7 \mathrm{c})^{3}\end{array}$ & 1155 & 453 & 2060 & 385 & 165 & 151 & \\
\hline \multirow[t]{3}{*}{ LP 2} & $\begin{array}{l}\text { Allometric } \\
\text { equation for } \\
\text { Ginkgo biloba }{ }^{1} \text {. }\end{array}$ & 276 & 109 & 489 & 92 & 39 & 36 & \\
\hline & $\begin{array}{l}290 \mathrm{Mg} \mathrm{ha}^{-1} \\
(\text { Fig. } 7 \mathrm{c})^{3}\end{array}$ & 532 & 210 & 951 & 177 & 76 & 70 & \\
\hline &  & 734 & 291 & 1310 & 245 & 105 & 97 & \\
\hline
\end{tabular}

1. Equation for above ground woody biomass for Ginkgo biloba from Yoon et al (2013) using wood density from BenHua et al. (2000).

2. ANNP calculated using mean, mean minimum, and mean maximum thicknesses of tree rings from 8 wood specimens from the Buckley Fm. in the Beardmore area; tree ring thickness data from Taylor and Ryberg (2007).

3. High/ low estimates of above ground biomass based on biomass of modern forests with basal areas equivalent to LP 1 and LP2 (Fig. 7).

4. eNPP (ecologically and evolutionarily relevant NNP), the monthly rate of addition of above ground biomass during the growing season. Estimate of 3 month growing season is based on Francis et al. (1994) and Taylor and Ryberg (2007); 7 month growing season is based on Spicer and Herman (2010).

Table 2: Estimates of Annual Net Primary Productivity (biomass produced each year) and eNPP (biomass produced monthly during growing season) for Lamping Peak 1 and 2 forests. Values vary based on which estimates of biomass, and of tree ages, as determined by the measure of tree ring thickness (mean, minimum, maximum, from Taylor and Ryberg, 2007) that are applied, and, for eNPP, the estimate of duration of growing season. 


\begin{tabular}{|c|c|c|c|c|c|}
\hline & $\begin{array}{l}\text { Graphite } \\
\text { Peak }^{1 .}\end{array}$ & $\begin{array}{l}\text { Mt. } \\
\text { Achernar }\end{array}$ & $\begin{array}{l}\text { Wahl } \\
\text { Glacier } \\
\text { 3. }\end{array}$ & $\begin{array}{l}\text { Lamping } \\
\text { Peak } 1^{3,4}\end{array}$ & $\begin{array}{l}\text { Lamping } \\
\text { Peak } 2^{3,4}\end{array}$ \\
\hline $\begin{array}{l}\text { Number of } \\
\text { stumps }\end{array}$ & 5 & 15 & 13 & 53 & 21 \\
\hline $\begin{array}{l}\text { Diameter } \\
(\mathrm{cm})\end{array}$ & 39 & 11 & 26 & 21 & 39 \\
\hline Height (m) & 25 & 10 & 19 & 15 & 25 \\
\hline $\begin{array}{l}\text { Density } \\
\left(\text { trees ha }^{-1}\right)\end{array}$ & 23 & 2134 & 263 & 2505 & 1185 \\
\hline $\begin{array}{l}\text { Basal area DGL } \\
\left(\mathrm{m}^{2} \mathrm{ha}^{-1}\right)\end{array}$ & & 65 & 18 & 174 & 194 \\
\hline $\begin{array}{l}\text { Basal area DBH } \\
\left(\mathrm{m}^{2} \mathrm{ha}^{-1}\right)\end{array}$ & 14.8 & & 14 & 65 & 80 \\
\hline $\begin{array}{l}\text { Biomass } \\
\left(\mathrm{Mg} \mathrm{ha}^{-1}\right)\end{array}$ & NA & NA & NA & $\begin{array}{c}139 \\
(225-340)\end{array}$ & $\begin{array}{c}178 \\
(290-400)\end{array}$ \\
\hline
\end{tabular}

${ }^{1 .}$ From Gulbranson et al. $(2012,2014)$

2. From Taylor et al. $(1992,2000)$

3. From Knepprath (2006)

4. This study

Table 3. Characteristics of high latitude Permian forests preserved in the Buckley Formation in the Beardmore Glacier area. All fossil forests are within $100 \mathrm{~km}$ of Lamping Peak. 


\begin{tabular}{|c|c|c|c|c|c|c|c|}
\hline & $\begin{array}{l}\text { Lamping } \\
\text { Peak }^{1 .}\end{array}$ & $\begin{array}{l}\text { Gordon } \\
\text { Valley }\end{array}$ & $\begin{array}{l}\text { Curio } \\
\text { Bay }{ }^{4}\end{array}$ & $\begin{array}{l}\text { Ohanga } \\
\text { Bay. }\end{array}$ & Stenkul Fiord $^{6}$ & Axel Heiberg ${ }^{7}$ & Axel Heiber \\
\hline Paleolatitude & $75^{\circ} \mathrm{S}$ & $70^{\circ} \mathrm{S}$ & $66^{\circ} \mathrm{S}$ & $66^{\circ} \mathrm{S}$ & $76^{\circ}-79^{\circ} \mathrm{N}$ & $75^{\circ}-85^{\circ} \mathrm{N}$ & $75^{\circ}-85^{\circ} \mathrm{N}$ \\
\hline $\begin{array}{c}\text { Age } \\
\text { Location }\end{array}$ & $\begin{array}{l}\text { Permian } \\
\text { CTM }^{2 . .}\end{array}$ & $\begin{array}{l}\text { Triassic } \\
\text { CTM }^{2} \text {. }\end{array}$ & $\begin{array}{l}\text { Jurassic } \\
\text { New } \\
\text { Zealand }\end{array}$ & $\begin{array}{l}\text { Jurassic } \\
\text { New } \\
\text { Zealand }\end{array}$ & $\begin{array}{c}\text { Eocene (Ear) } \\
\text { Arctic } \\
\text { Canada }\end{array}$ & $\begin{array}{c}\text { Eocene (Mid) } \\
\text { Arctic } \\
\text { Canada }\end{array}$ & $\begin{array}{c}\text { Eocene (Mi } \\
\text { Arctic } \\
\text { Canada }\end{array}$ \\
\hline $\begin{array}{c}\text { Dominant tree } \\
\text { types }\end{array}$ & $\begin{array}{l}\text { Glossop- } \\
\text { terids }\end{array}$ & $\begin{array}{l}\text { Podo- } \\
\text { carps }\end{array}$ & $\begin{array}{l}\text { Podo- } \\
\text { carps }\end{array}$ & Conifers & $\begin{array}{l}\text { "Meta- } \\
\text { sequoia" }\end{array}$ & $\begin{array}{l}\text { "Meta- } \\
\text { sequoia" }\end{array}$ & $\begin{array}{l}\text { "Meta- } \\
\text { sequoia" }\end{array}$ \\
\hline $\begin{array}{l}\text { Diameter } \\
\text { (mean; cm) }\end{array}$ & $21-39$ & 28 & 16 & 25 & 76 & 35 & 23 \\
\hline Height (m) & $15-25$ & 20 & 14 & 19 & $32-36$ & $37-43$ & $23-27$ \\
\hline $\begin{array}{c}\text { Density } \\
\left(\text { trees ha }^{-1}\right)\end{array}$ & $1185-2505$ & 274 & 851 & 2153 & 300 & 127 & 396 \\
\hline $\begin{array}{c}\text { Basal area } \\
\left(\mathrm{m} \mathrm{ha}^{-1}\right)\end{array}$ & $65-80$ & 21 & 16 & 146 & 96 & 117 & 30 \\
\hline $\begin{array}{l}\text { Biomass } \\
\left(\mathrm{Mg} \mathrm{ha}^{-1}\right)\end{array}$ & $\begin{array}{l}139-178 \\
225-400\end{array}$ & NA & 579 & 579 & $502-513$ & 644 & 76 \\
\hline
\end{tabular}

${ }^{1}$ Knepprath, 2006; this study

2. Central Transantarctic Mountains

3. Cuneo et al., 2003

4. Pole, 1999

5. Thorn, 2005

6. Williams, 2007

7. Williams et al., 2003

Table 4. Characteristics of selected high latitude fossil forests, modified from Williams, (2007). 